\title{
The Architectural Legacy of Stanisław Bukowski in Vilnius - a Contribution to Further Research
}

\section{Sebastian Wicher}

Sleńdziński Gallery in Białystok

s.wicher@galeriaslendzinskich.pl

This article is a supplement to the author's monograph entitled Żyć architektura. Życie i twórczości Stanistawa Bukowskiego (1904-1979), published in 2009. The author presents the less known activity of Bukowski as an architect, town planner and conservator of monuments in Vilnius and its area in the years 1936-1945.

Keywords: architect Stanisław Bukowski (1904-1979), modern architecture, architecture and urban planning in Vilnius, Vilnius monuments, artistic life in Vilnius, interwar period in Vilnius, Vilnius during World War II. 


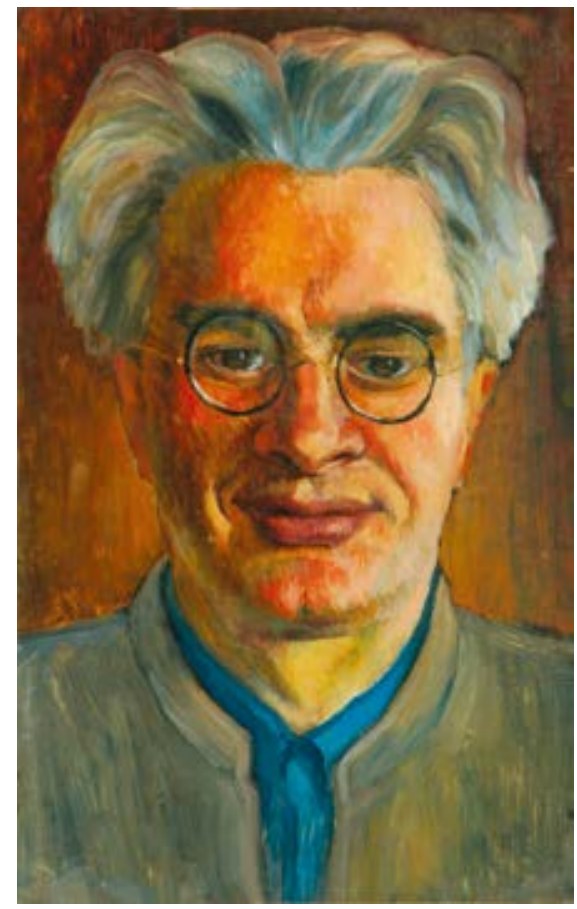

1.

A portrait of Stanistaw Bukowski by Krystyna Wróblewska, 1941, from the collection of Joanna Łempicka

Krystyna Wróblewska, Stanistawo Bukowskio portretas, 1941

Stanisław Bukowski [illus. 1] was an architect and urban planner, who earned his reputation in Polish historiography as the person behind the restoration of monuments destroyed during World War II in Białystok. The restoration of the late baroque residence of the Branicki family became his opus magnum. Yet before he arrived in Białystok in April 1945, he had spent nearly ten years living in Vilnius. Bukowski is the only architect from Białystok whose life and work have been chronicled in a monograph ${ }^{1}$. It is a summary of the research based on previous publications devoted to the architect. As far as the Vilnius period is concerned, the publication was a

1 Sebastian Wicher, Żyć architektura. Życie i twórczość architekta Stanisława Bukowskiego (1904-1979) (To live architecture. Life and work of architect Stanisław Bukowski (19041979)), Białystok: Stowarzyszenie Architektów Polskich Oddział w Białymstoku, Studio Wydawnicze Unikat, 2009. The work was published on the initiative of Janusz Kaczyński, the deputy head of the Białystok branch of the Association of Polish Architects at the time. The publication is an edited and elaborated MA dissertation entitled Twórczość architekta Stanistawa Bukowskiego w obszarze architektury wspótczesnej i zabytkowej na tle epoki (Architectural work of Stanisław Bukowski in respect to modern and historic architecture of his times) written by Sebastian Wicher in 2002 under the supervision of Prof. Jan Tajchman Sc.D at the Faculty of Fine Arts of the Nicolaus Copernicus University in Torun. In 2009 Sleńdziński Gallery in Białystok held a retrospective exhibition devoted to Stanisław Bukowski prepared by Izabela Suchocka and me, which was entitled the same as the monograph. 


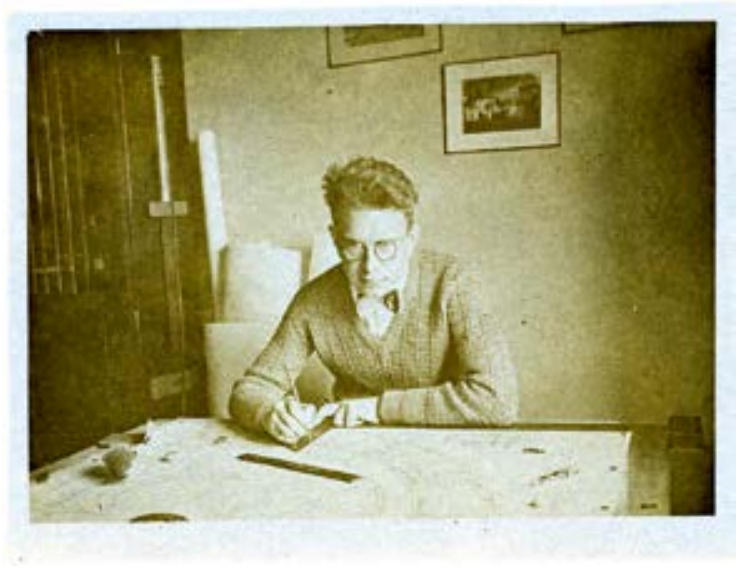

2.

Stanisław Bukowski at work in an architecture studio, late 1920 s to early 1930 s, Sleńdziński Gallery in Białystok collection

Stanisławas Bukowskis dirba architektūros studijoje, XX a. 3 deš. pab. -4 deš. pr.

minor extension of known research, which was due to the lack of an inquiry into Lithuanian archives. The analysis was based solely on the materials available in private Polish collections ${ }^{2}$ and publications from the interwar period and recent years. Therefore, this paper is limited to the period which the architect spent in Vilnius as well as to the new findings revealed by Polish and Lithuanian researches.

Stanisław Bukowski was born on 21 January 1904 in Rypin (a city in Lipno county in the Kuyavian-Pomeranian Voivodeship) ${ }^{3}$. He lived in Warsaw with his parents and three siblings from 1914. At the age of sixteen he served as a volunteer during the Polish-Soviet War of 1920 although on the account of his young age he was assigned to auxiliary service in the Supply Department of the 16th Pomeranian Infantry Regiment. On 1 October 1920 Bukowski was exempted in order to continue his education at the Tadeusz Reytan grammar school ${ }^{4}$. In 1922 he began studying architecture at Warsaw University of Technology from where he graduated in $1933^{5}$ [illus. 2]. In those eleven years at university he met the most distinguished lecturers who

2 The collection of Joanna Łempicka and her sister Małgorzata Siedlecka (d. 2018) from Białystok, Placyda Siedlecka's nieces, is currently in deposit in the Sleńdziński Gallery in Białystok (presently being analysed). Additionally, the collection of Jerzy Stadnicki from Warsaw (d. 2002), Alina Bukowska's husband - she was Bukowski's cousin. Stadnicki sold part of the collection, which has not yet been analysed, to the National Library of Poland in the 1980s. The part of the collection which he kept has now been dispersed.

3 Sebastian Wicher, op. cit., p. 13.

4 Warsaw University of Technology, Student Registration Department, Student Files Archive, [Stanisław Bukowski's File], No. 7243 (later: WUT): Biography, no pagination.

5 WUT, Authorising document of the Dean of the Faculty of Architecture at Warsaw University of Technology No. 8/33, dated 7 April 1933, no pagination. 


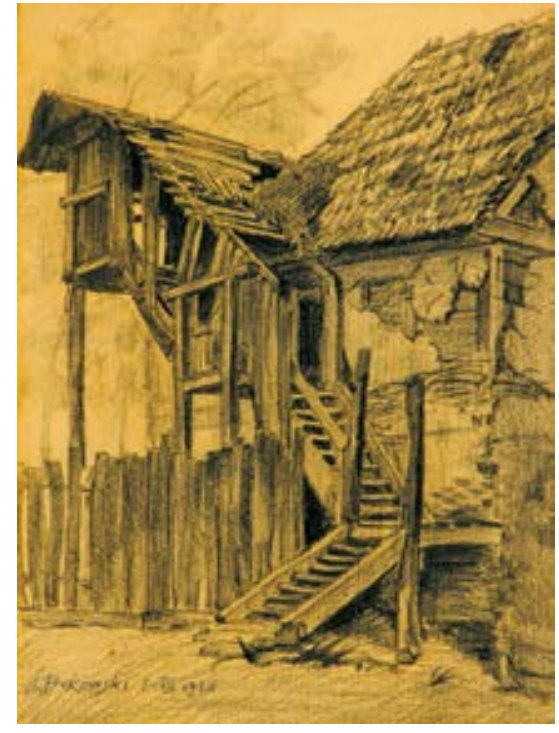

3.

A drawing entitled Schody na Powiślu (Steps in Powiśle) by Stanisław Bukowski, on display in City Art Gallery in Łódź in 1925, Sleńdziński Gallery in Białystok collection

Stanisławas Bukowskis, Pavyslio laiptai, Lodzès meno galerija, 1925

created the design movement called the Warsaw School of Architecture ${ }^{6}$. Prof. Rudolf Świerczyński was Bukowski's thesis advisor ${ }^{7}$. Thanks to the efforts of Prof. Czesław Przybylski, the Ministry of Religious Affairs and Public Education awarded Bukowski an annual scholarship in Italy, during which he also visited the Czech Republic ${ }^{8}$. In the academic year 1934/1935 Bukowski was a senior assistant to Prof. Franciszek Krzywda-Polkowski at the Department of Interior and Landscape Design ${ }^{9}$, which was known for its novel academic syllabus. Prof. Tadeusz Tołwiński, who was an excellent urban planner and an active member of the Society for the Preservation of Historical Monuments, was Bukowski's lecturer in Urban Construction. Prof. Oskar Sosnowski was yet another academic Bukowski had a chance to meet and after 1945 he also had the opportunity to continue several of the

6 Prof. Konrad Kucza-Kuczyński characterised the term in detail in: Twórcy i dzieła Warszawskiej Szkoty Architektury 1915-2015 (Creators and works of Warsaw School of Architecture 1915-2015), Warszawa: Oficyna Wydawnicza Politechniki Warszawskiej, 2017.

7 National Library of Poland, Manuscript Department (later: NLP), [Materiały dotyczące biografii Stanisława Bukowskiego, jego działalności zawodowej i twórczości], f. Rps akc. 12134: S. Bukowski's student's index, no pagination.

8 NLP, [Materiały dotyczące biografii Stanisława Bukowskiego, jego działalności zawodowej i twórczości], f. Rps akc. 12134: Authorising document of the Head of the Ministry of Religious Affairs and Public Education No. Iv.Szt-8969/33 dated 12 September 1933, no pagination.

9 Politechnika Warszawska. Sktad osobowy i plan studiów na rok akademicki 1934/35 (Warsaw University of Technology. Faculty composition and syllabus for academic year 1934/35), Warszawa: Politechnika Warszawska, 1934, p. 32. 
professor's projects and restore ruined buildings which he had designed, for instance, St. Roch Church in Białystok, the Church of Saint Agnes in Gonią$\mathrm{dz}$, the Church of the Assumption of the Blessed Virgin Mary in Hodyszewo or the historic former monastery in Wigry ${ }^{10}$. All the aforementioned lecturers and masters who Bukowski came into contact with represented, to a varying degree, avant-garde tendencies in architecture. Bukowski spent many years studying at university, which allowed him to make the acquaintance of several faculty alumni such as Jan Zachwatowicz, Piotr Biegański, Józef Szanajca, and Stanisław Marzyński, many of whom were as outstanding as their professors.

At university Bukowski did an architecture and construction internship during a summer holiday break. This internship was a project involving apartment blocks and commercial buildings in Warsaw ${ }^{11}$ and Gdynia ${ }^{12}$. He also compiled an architectural inventory of the Wilanów Palace together with a certain Walczak (Henryk or Tadeusz, they were both alumni of the

10 Sebastian Wicher, op. cit., p. 51 .

11 From 1 July to 1 August 1923 he participated in the construction of an administrative settlement at 27 Nowowiejska St in Warsaw, which was a part of the so-called Kolonia Staszica by Polish Building Society, and from 23 June to 1 October 1925 he was involved in the construction of a warehouse for the Warsaw Provision Department at the City Hall at 16 Stawki St, which was executed by an engineering company under the name of Przedsiębiorstwo Robót Inżynieryjnych i Budowlanych W. Paszkowski i F. Próchnicki i Ska [in: NLP, [Materiały dotyczące biografii Stanisława Bukowskiego, jego działalności zawodowej i twórczości], f. Rps akc. 12134: An authorising document of Polish Bulding Society No. 1996/23 dated 18 August 1923, no pagination and an authorising document by W. Paszkowski dated 7 October 1925, no pagination].

12 He worked in Gdynia from 23 July to 23 October 1930 as deputy chief at the construction site on the building of two houses in Orłowo quarter (Majewski's house and Żebrowski's house), a comprehensive school, and the interior of a Civic Club, all of which were projects of the architecture studio belonging to Włodzimierz Prochaska and Tadeusz Jędrzejewski, excellent Polish architects of those times [in: NLP, [Materiały dotyczące biografii Stanisława Bukowskiego, jego działalności zawodowej i twórczości], f. Rps akc. 12134: authorising document by W. Prochaska and T. Jędrzejewski dated 23 October 1930, no pagination]. The prestigious studio as well as the internship location might have been connected to Marian Bukowski (1902-1939) - Stanisław's older brother, a great architect specialising in hydraulic engineering and Warsaw University of Technology graduate (1926) - who lived in Gdynia from 1928 and worked as the head of the Hydraulic Engineering and Roadwork Department in the Maritime Authority Office and the closest colleague of Tadeusz Wenda, the creator of the Port of Gdynia. Marian Bukowski was killed by the Germans as a hostage in Piaśnica on 11 November 1939 [after: Stanisław Łoza, Czy wiesz kto to jest? (Do you know who this is?), Warszawa: Wydawnictwo Głównej Księgarni Wojskowej, 1938, p. 85; Małgorzata Sokołowska, Wiesława Kwiatkowska, Gdyńskie cmentarze. O twórcach miasta, portu $i$ floty (Cemeteries of Gdynia. About the creators of the city, port and fleet), Gdynia: Oficyna VERBI CAUSA, 2003, pp. 109, 302. 


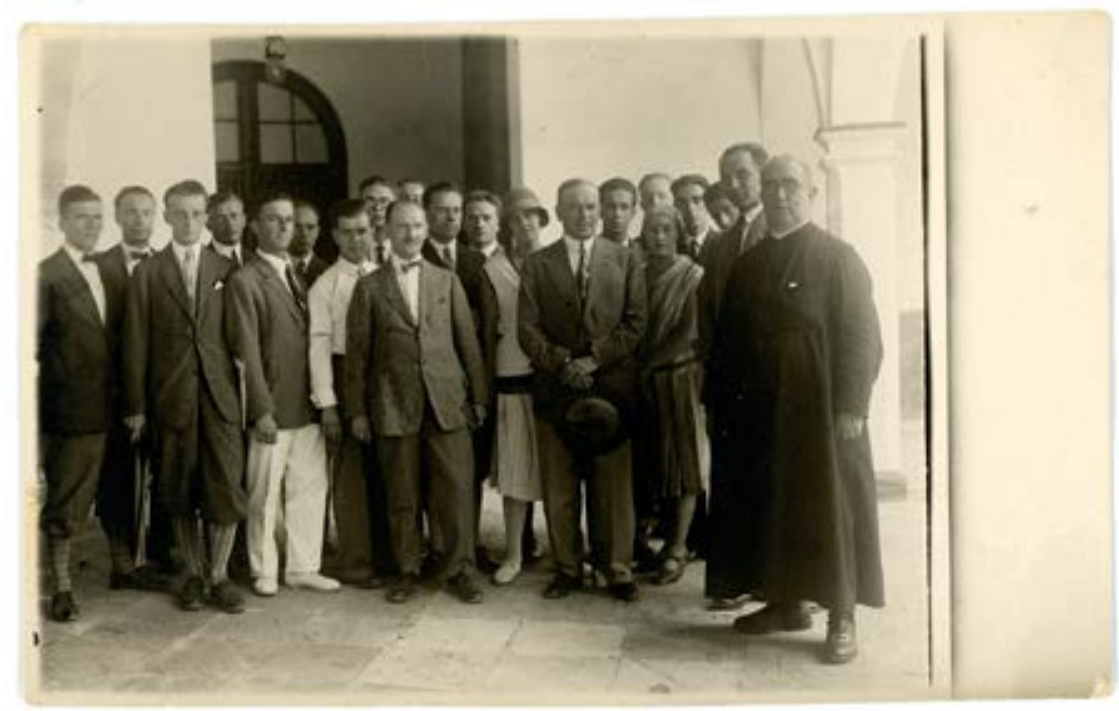

4.

A group of students with Prof. Czesław Przybylski (with hat) and Prof. Zygmunt Kamiński (in the centre with notebook) during a trip abroad in 1928, Sleńdziński Gallery in Białystok collection
Studentai su prof. Czesławu Przybylskiu (su kepure) ir prof. Zygmuntu Kamińskiu (centre, su užrašu knygute) kelionès į užsienį metu, 1928

Faculty of Architecture of Warsaw University of Technology $)^{13}$. In addition, he was also an intern in Prof. Czesław Przybylski's architecture studio ${ }^{14}$.

Apart from his work as an architect, Bukowski made some extra money by designing posters, advertisements, and shop windows, for instance, for his brother-in-law Erwin Pescht and his brother Jerzy, who owned a shop with photography accessories in Warsaw ${ }^{15}$. He was a skilled illustrator, too. His works were presented at an exhibition in the City Art Gallery in Łódz in 1925 [illus. 3] organised by the Auditing Students' Association at

13 The inventory of the Wilanów Palace took place during the restoration of the building from 1 June to 15 November 1926, from 1 May to 1 November 1927, and finally from 1 May to 1 November 1928, and it was supervised by the architect Jarosław Wojciechowski, a restoration lecturer at the Faculty of Architecture of the Warsaw University of Technology; after NLP [Materiały dotyczące biografii Stanisława Bukowskiego, jego działalności zawodowej i twórczości], f. Rps akc. 12134: [authorising document by Jarosław Wojciechowski dated 23 June 1930, no pagination]. Excerpts of the palace inventory and photographs of its then condition were published in the article by: Jarosław Wojciechowski „Pałac Wilanowski i jego obecna restauracja” (Wilanów Palace and its current restoration), in: Architektura i Budownictwo, 1928, No. 3, pp. 81-106.

14 It took place from 1 May to 1 October 1933 [after: NLP, [Materiały dotyczące biografii Stanisława Bukowskiego, jego działalności zawodowej i twórczości], f. Rps akc. 12134: authorising document by Czesław Przybylski dated 22 October 1934, no pagination].

15 Sebastian Wicher, op. cit., pp. 13, 150-151. 
the Faculty of Architecture of Warsaw University of Technology. Other presented pieces included works by Bukowski's professors and fellow students, for example, Stanisław Noakowski, Józef Szanajca, Leon Suzin, or Juliusz Żórawski ${ }^{16}$. In 1929 several of his drawings were published in an architecture magazine Architektura $i$ Budownictwo to serve as an illustration for an article by Edmund Michalski „Wrażenia z podróży do Hiszpanji”. The article recounted a trip to Spain made by around 40 students from the Auditing Students' Association of the Faculty of Architecture of Warsaw University of Technology and their professors Czesław Przybylski and Zygmunt Kamiński. Apart from Spain, they also visited France, Italy and Morocco ${ }^{17}$ [illus. 4].

After graduating and completing his assistantship at the Faculty of Architecture at Warsaw University of Technology, Bukowski decided to transfer to Vilnius in 1936, where he was employed as a contracted architect in the Miejskie Biuro Urbanistyczne (later: City Bureau for Urban Development $)^{18}$. His resignation from his post at his home university may have been caused by the death of his mentor, Prof. Czesław Przybylski (d.1936), or by a tempting opportunity to apply his knowledge of modern urban planning.

The City Bureau for Urban Development was founded by the President of Vilnius Wiktor Maleszewski and the person in charge of it was Prof. Romuald Gutt from Warsaw ${ }^{19}$, whom Bukowski had met at university. Jerzy Kobzakowski became Gutt's deputy and other newly hired architects included Jan Peksza (Pekszo) and Leszek Teodozy Dąbrowski. The professor and his new staff were praised by Fr Piotr Śledziewski PhD - an art historian and a photographer ${ }^{20}$ [illus. 5], - in his article from 1936 in

16 Bukowski presented three works Schody na Powiślu (Steps in Powiśle), Dworek na Powiślu (Manor house in Powiśle) and Mury staromiejskie (Old-town walls), see: NLP, [Materiały dotyczące biografii Stanisława Bukowskiego, jego działalności zawodowej i twórczości], f. Rps akc. 12134: Wystawa „Związku Słuchaczów Architektury Politechniki Warszawskiej” (Exhibition of Auditing Students' Association at Warsaw University of Technology), Łódź: Miejska Galeria Sztuki w Łodzi, styczeń- luty 1925, p. II.

17 Edmund Michalski, „Wrażenia z podróży do Hiszpanji” (Impressions from a trip to Spain), in: Architektura i Budownictwo, 1929, No. 5, pp. 186-195.

18 NLP, [Materiały dotyczące biografii Stanisława Bukowskiego, jego działalności zawodowej i twórczości], f. Rps akc. 12134: A copy of a document No. 367/BU by the Secretary of the Personnel Department of the Executive Committee in Vilnius dated 7 May 1941, which authorised employing S. Bukowski in the City Bureau for Urban Development in Vilnius from 1 July 1936 to 1 January 1940, no pagination.

19 J. Ch., „Wojna o Wilno” (A War over Vilnius), in: Dziennik Wileński, 1936, No. 102, p. 7.

20 Piotr Śledziewski (1884-1950), a Catholic priest, doctor of Philosophy, photographer, Polish Army chaplain, in the years 1919-1920 he was a conservator of the historic monuments in the Conservation Office in Łomża and Białystok, after 1945 the head of the Culture Department at Białystok Voivodeship Office [after: „Piotr Śledziewski”, in: Wikipedia - The Free Encyclopedia, [online], [cited 2019-11-28], https://pl.wikipedia.org/wiki/Piotr_Śledziewski]. 


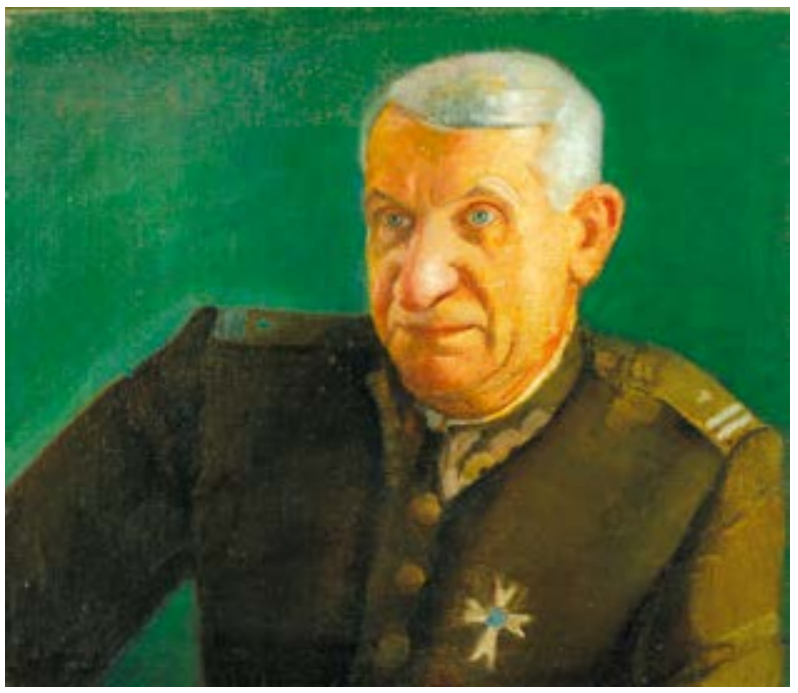

5.

A portrait of $\mathrm{Fr}$ Piotr Śledziewski $P h D$ by Placyda Siedlecka-Bukowska, 1938, Sleńdziński Gallery in the Białystok collection

Placyda Siedlecka-Bukowska, Dr: Piotro Śledziewskio portretas, 1938

Kurjer Wileński, where he wrote that the architects are "energetic, talented, and demonstrate knowledge of Western urban planning"'21. All these architects were Faculty of Architecture alumni at Warsaw University of Technology and Peksza also studied architecture in Vilnius and Lviv. The office was located in a former monastery at 2 Dominikańska St. (now Dominikonu St. 6$)^{22}$. Each of the architects was responsible for creating a development plan for particular areas of the city and in addition to that Kobzakowski was the author of the General Urban Development Plan of Vilnius. It was based on the modern urban development plan of Warsaw confirmed by the City Hall in February of $1939^{23}$.

Due to Gutt's frequent absences in Vilnius and because of the fact that the majority of staff came from outside Vilnius, the Office often received a dose of harsh yet humorous criticism from the public and the local artistic establishment represented by Ludomir Sleńdziński, Marian Morelowski, Mieczysław Limanowski, or Kazimierz Kieniewicz. His opponents pointed out that Gutt did not come from Vilnius and was not familiar with

21 Piotr Śledziewski, „Sprawa dwóch pomników w Wilnie - Marszałka Piłsudskiego i Mickiewicza" (The case of two monuments in Vilnius - of Marshall Piłsudski and Mickiewicz), in: Kurjer Wileński, 1936, No. 229, p. 7.

22 „Przyszłe Wilno: 1. Biuro Urbanistyczne” (Future Vilnius: 1 Urban Planning Office), in: Dziennik Wileński, 1937, No. 104, p. 4.

23 (z), „Strefy budowlane Wilna w opracowaniu Miejskiego Biura Urbanistycznego” (Construction Zones in Vilnius elaborated by The City Bureau for Urban Development), in: Kurjer Wileński, 1939, No. 60, p. 5. 


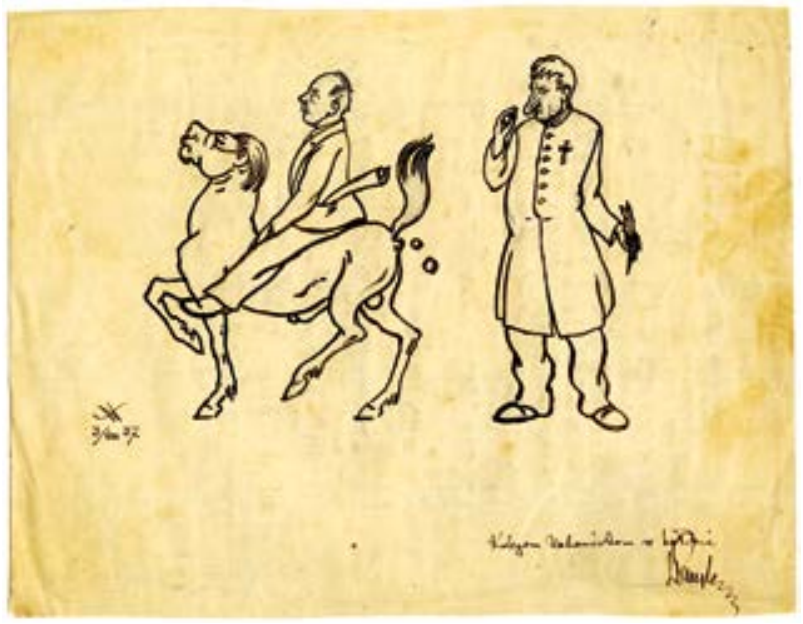

6.

A satirical drawing dedicated to urban planners from the City Bureau for Urban Development in Vilnius by S. Narębski, dated 3 August 1937, S. Bukowski is depicted as a horse being ridden by $\mathrm{R}$. Gutt and they are both being blessed by Fr Piotr Śledziewski PhD, Sleńdziński Gallery in Białystok collection

Stefanas Narębskis, Satyrinis piešinys, dedikuotas Vilniaus miesto matavimo ir planavimo valdybos darbuotojams, $1937 \mathrm{~m}$. rugpjūčio 3 d.; Stanisławas Bukowskis raitas ant arklio kartu su Romualdu Guttu, juos šventina dr. Piotras Śledziewskis

the local particularities ${ }^{24}$. In spite of that, urban planners enjoyed his trust and were assigned demanding and complex tasks. In a letter to his wife from 20 September 1938, Stanisław Bukowski wrote:

There is no chance for some time off, but I might get away. I'm so dog-tired. No man can carry on doing such back-breaking work, especially with my poor health $<\ldots>$ Gutt, Scholtzówna and Śledziewski left only an hour ago <...> Gutt was trying to joke around as usual, but I wasn't in the mood for it. ${ }^{25}$ [illus. 6]

Young architects applied the most groundbreaking urban developments while working on their project designs. Nearly four years after the establishment of the office, a number of projects of squares (among them Katedralny Square (now Katedros Square), Ratuszowy Square (now Rotušès Square), Orzeszkowa Square (now Vincas Kudirka Square), the square in front of the Towarzystwo Przyjaciół Nauk w Wilnie (Society of Friends of Learning in Vilnius) building or the area near the railways station), streets, parks and housing estates were completed. Greenery was to be the key

24 It is strongly suggested by numerous articles in the local press. In 1937 Teodor Bujnicki (1907-1944), a well-known Vilnius poet, satirist, and literary critic published a satire in verse entitled Memoriał w sprawie urbanistyki wileńskiej o prawdziwa estetykę miasta (A memorial for city aesthetics regarding urban planning in Vilnius), Wilno: Zakłady Graficzne Znicz, 1937. A quote: We $l l$ put Master Gutt / by Bukowski's side. There they'll stand. / May the people of Vilnius and these new faces get acquaint.

25 Bukowski's letter to his wife Placyda Siedlecka-Bukowska dated 20 September 1938, in the collection of Joanna Łempicka from Białystok. 


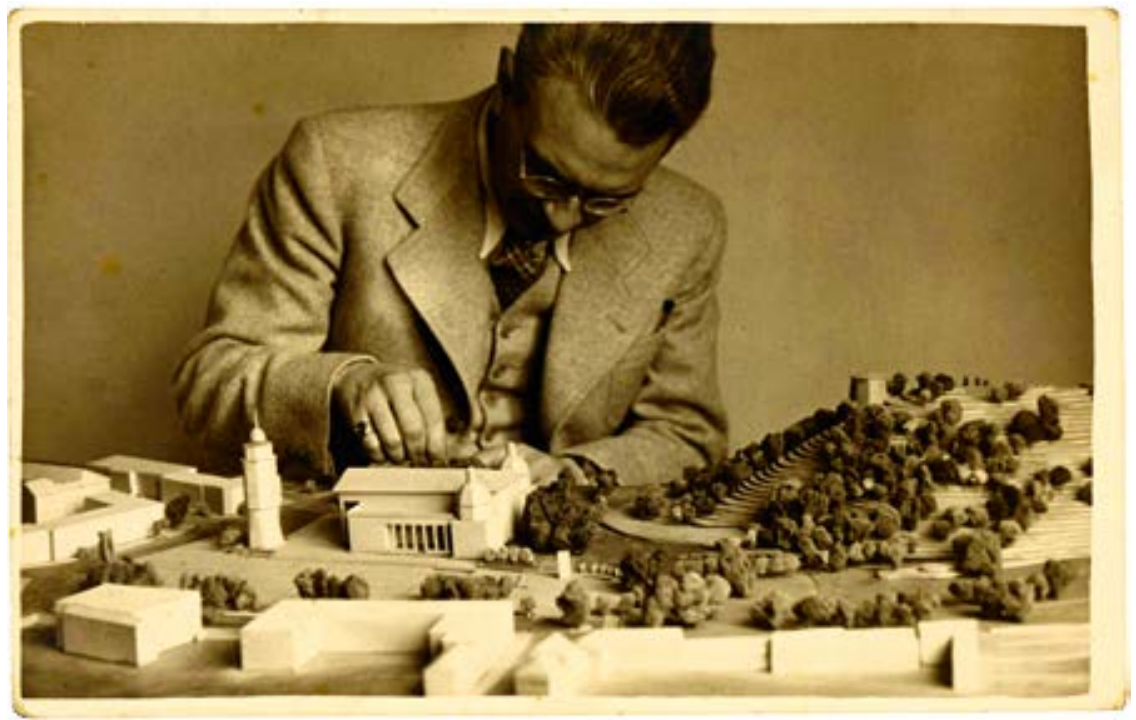

7.

S. Bukowski next to a model of the Cathedral Square in Vilnius, ca. 1937, from the collection of the National Library of Poland in Warsaw, Iconographic Collections Department, file No. F.66351/I
Stanisławas Bukowskis šalia Vilniaus Katedros aikštės modelio, apie 1937

element, especially in the area from Góra Zamkowa (now Gedimino Hill) through Trzykrzyska (now Trijų Kryžių Hill), Altaria (now Kalnų Park), Gaj Antokolski (now currently around Vasaros and Pavasario Streets) to Pośpieszki (now currently around the Pavilniai Regional Park) - the latter was to be a green wedge including natural looking parks. Furthermore, it was planned to build sports parks in the desolated section of Bouffałowa Mountain (now Taurakalnis) and on the left bank of the Wilia River (now Neris River). Promenades were going to be built on both sides of the river ${ }^{26}$.

One of the most controversial projects, however, concerned the regulation of the Katedralny Square in Vilnius. The work on the design started in 1937 and was supervised by Romuald Gutt. Stanisław Bukowski (who created the model of the square) worked on it together with his colleague Leszek Teodozy Dąbrowski. The main idea behind the project was to find a satisfactory solution to logistic and visual issues by arranging three basic elements of the project (a cathedral square, a square for official ceremonies

26 (S), „Zadrzewienie ulic, parki, bulwary... Plany Biura Urbanistycznego” (Tree planting in streets, parks and promenades... Bureau for Urban Development plans), in: Dziennik Wileński, 1937, No. 15 , p. 5 . 
and a pilgrim square), introducing green spaces and light displays [illus. 7]. The artistic community of Vilnius presented a competitive project by a renowned artist Ludomir Sleńdziński, which was characterised by a greater regularity of the square that was to be surrounded by numerous symbolic sculptures ${ }^{27}$ [illus. 8]. The project developed by the urban planners was approved by the City Hall and the City Council in May 1937 and also the following year by the Ministry of Internal Affairs. It was partly implemented in 1939-1941 with minor changes by a Lithuanian architect Vytautas Landsbergis-Žemkalnis ${ }^{28}$.

The monument of Marshall Józef Piłsudski was to constitute the main element of the square and tenders were invited for a project in 1939. The panel consisted of Bukowski, Fr Piotr Śledziewski PhD, Mieczysław Kotarbiński, Prof. Ludomir Sleńdziński, Prof. Marian Morelowski, conservator Witold Kieszkowski, Jerzy Hoppen and others as well as the chairman, General Kazimierz Sosnkowski. The official announcement of the results was held in the Northern Trade Fair pavilion on 18 April 1939. In the end, the panel did not select any of the 54 projects that had been sent, but it commissioned several artists to design the monument ${ }^{29}$. The project failed to be completed before the outbreak of World War II. The original idea was partially implemented when a statue of Gediminas, Grand Duke of

27 A precise description of the regulation was presented by Piotr Śledziewski and Stanisław Bukowski in: „O projekcie regulacji Placu Katedralnego w Wilnie w związku z zamierzoną budową pomnika pierwszego marszałka Polski Józefa Piłsudskiego" (On the project of regulation of the Cathedral Square in Vilnius in connection to the erection of the monument of the First Marshall of Poland Józef Piłsudski), in: Architektura i Budownictwo, 1938, No. 11/12, pp. 366-372 as well as numerous articles in Vilnius press. In the same issue a polemical article by Kazimierz Kieniewicz, „Problem Placu Katedralnego w Wilnie” (The matter of the Cathedral Square in Vilnius), pp. 373-375. Project design published in: Rasa Antanavičiūtè, Menas ir politika Vilniaus viešosiose erdvèse (Art and Politics in Vilnius Public Spaces), Vilnius: Lapas, 2019, il. 69.

28 Józef Poklewski, „Przyczynek do dziejów artystycznego Wilna w dwudziestoleciu międzywojennym" (Contribution to the history of art in Vilnius in interwar period), in: Studia z historii sztuki i kultury wilenskiej lat 1900-1945. Wybór tekstów (The study of art history and culture in Vilnius 1900-1945. Selected texts), Ed. Elżbieta Pilecka, Alicja Saar-Kozłowska, Małgorzata Wawrzak, Toruń: Wydawnictwo Naukowe Uniwersytetu Mikołaja Kopernika, 2019, pp. 170-171.

29 Piotr Śledziewski, „Sprawa dwóch pomników w Wilnie”, p. 7; „Konkurs na szkicowy projekt pomnika Marszałka Józefa Piłsudskiego w Wilnie” (A competition for a sketch design of Marshall Józef Piłsudski monument in Vilnius), in: Architektura i Budownictwo, 1939, No. 4/5, pp. 5759; „W 20-letnią rocznicę odzyskania Wilna” (On the 20th anniversary of regaining Vilnius), in: Gtos Narodowy, 1939, No. 107, p. 5; „Nie zakwalifikowano żadnego z 54 projektów na pomnik Marszałka Piłsudskiego" (None of the 54 projects of Piłsudski monument selected), in: Stowo, 1939, No. 106, p. 5; „Otwarcie wystawy prac ,grupy wileńskiej” i wystawa projektów na pomnik Marsz. Piłsudskiego” (Opening of the exhibition of works by 'Vilnius Group' and Piłsudski monument projects exhibition), in: Stowo, 1939, No. 107, p. 7. 


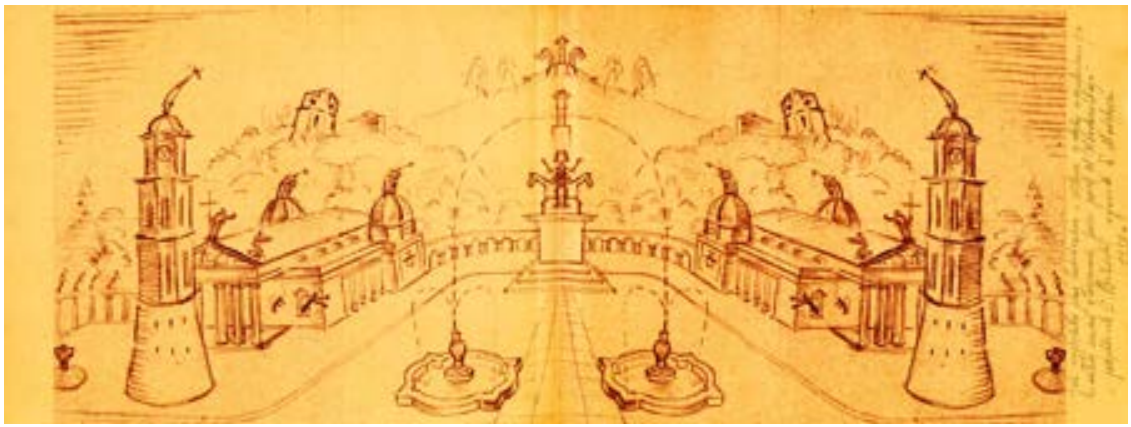

8.

A satirical drawing depicting the regulation of the Cathedral Square in Vilnius according to the idea of Marian Morelowski by Edmund Medeksza, 1938, Sleńdziński Gallery in Białystok collection
Edmundas Medeksza, Satyrinis piešinys, vaizduojantis Katedros aikštės pertvarkymą pagal Mariano Morelowskio idejją, 1938

Lithuania, designed by Vytautas Kašuba and Mindaugas Šnipas was placed in the space provided for the monument in 1996. The regulation of the Katedralny Square gained the most publicity in the interwar period together with the regulation of the Main Square in Kraków and the development of the area around the Royal Castle in Warsaw. Those three projects mae a significant contribution to the development of urban planning methods ${ }^{30}$.

The City Bureau for Urban Development also prepared a project for a Pilgrim Trail, which would lead from the Ostra Brama (now Aušros vartai) to the Basilica of St. Stanislaus via Arsenalska St. (now T. Vrublevskio and Arsenalo Streets), Derewnicka St. (now Rinktinės St.) to Kalwaria (now Kalvariju). The trail was going to be regulated, covered with gravel and planted with trees. The investment also included the construction of a new bridge on the Wilia River at the end of Arsenalska St. next to the Wróblewski Library. According to the press, the technical department of City Hall designed a steel arch bridge visually corresponding to the sur-roundings. The construction was supposed to begin in the first half of May $1938^{31}$. However, Mindaugas Bridge that now exists in that location (apart from a pontoon bridge from the 1960s) was only completed in 2003 . There is

30 Krzysztof Pawłowski, „Zasady ochrony, odbudowy i rewaloryzacji historycznych zespołów urbanistycznych" (Regulations concerning the preservation, renovation and restoration of historical urban complexes), in: Zabytki urbanistyki i architektury w Polsce. Odbudowa $i$ konserwacja, Ed. Wiktor Zin, vol. 1: Miasta historyczne, Ed. Wojciech Kalinowski, Warszawa: Arkady, 1986, p. 51.

31 „Aleja z Ostrej-Bramy do Kalwarji” (The alley from the Gate of Dawn to Kalwaria), in: Wieczorna Gazeta Wileńska, No. 58, 1938 p. 2. 


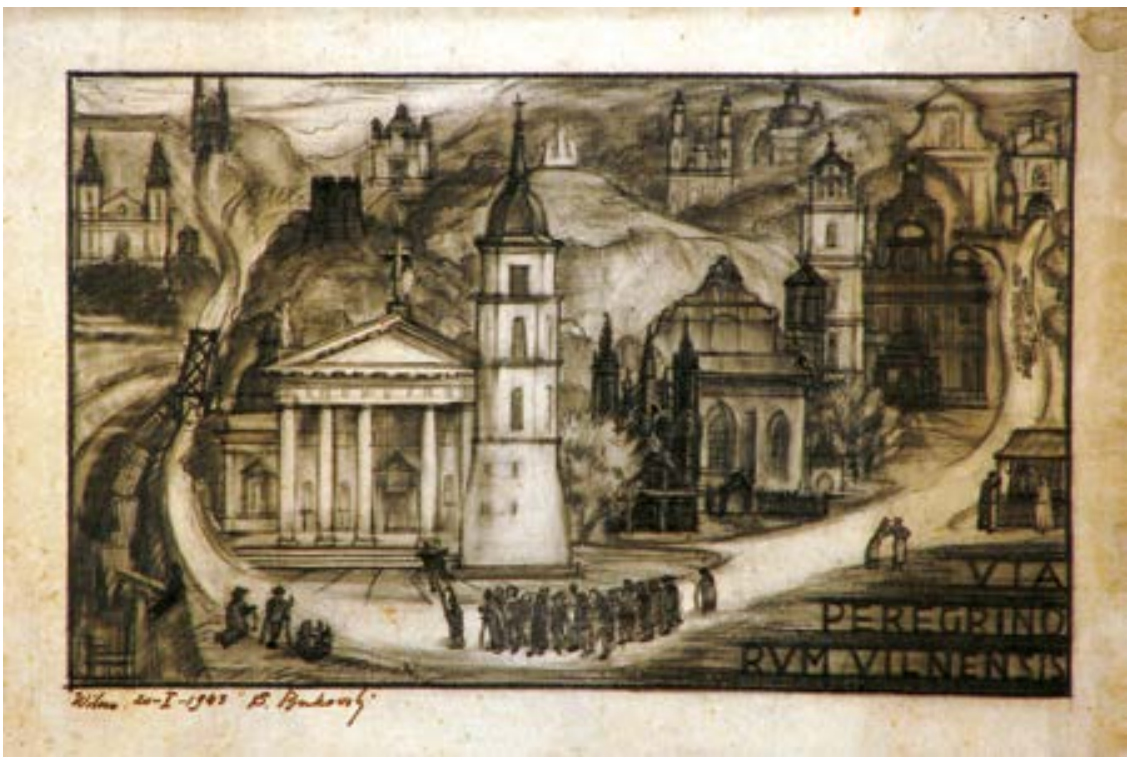

9.

A drawing entitled Via Peregrinorum Vilnensis by S. Bukowski, dated 20 January 1943, from the author's collection
Stanisławas Bukowskis, Via Peregrinorum Vilnensis, $1943 \mathrm{~m}$. sausio $20 \mathrm{~d}$.

a reason to believe that Bukowski was the creator of the Pilgrim Trail - his drawing dated 20 January 1943 was entitled "Via Peregrinorum Vilnensis" and its aesthetics resembles the work of Prof. Sleńdziński² [illus. 9].

Another individual project by Bukowski was an urban planning graphics of the regulation of the area along the Wilia River bank, specifically I Bateria Konna St. (now A. Goštauto St.) and the section between the Church of St. Philip and St. Jacob (now Vasario 16-osios St.) and the Zielony Bridge (now Žaliasis Bridge). The author presented the project at a City Hall meeting in April 1938 in the following way:

it was envisaged as a promenade retained in a shape of a triangle with park-style landscaping $<\ldots>$ the proposed scattered buildings provide a gentle transition from the open space of the promenade to the compact city centre area and address the need for more air, greenery and architectural balance in the district. 
The arrangement of the greenery along the promenade of I Bateria St. has been designed to expose some of the remarkable examples of architecture as well as to create a recreational space for the local residents. The project was approved unanimously. ${ }^{33}$

At the same meeting Bukowski and Kobzakowski presented a model - described as "beautiful" by a Kurjer Nowogródzki reporter - of the train station redevelopment and a regulation of the train station square. The success of the plan depended on the agreement with the railway authorities ${ }^{34}$ and with minor changes, it was implemented during the Soviet occupation of Vilnius ${ }^{35}$.

After two years of work Bukowski and Kobzakowski must have gained considerable experience since they were selected to join the fifty surveyors in the Association of Polish Cities (together with R. Gutt, T. Tołwiński, and W. Czarnecki) ${ }^{36}$. During the meeting of the Board of Surveyors of the Association of Polish Cities on 12 December 1938 its members examined the project for Druskienniki (now Druskininkai) spa town development, which was prepared by the Regional Development Planning Office for Białystok Voivodeship. The project was evaluated by Stanisław Bukowski and Jerzy Kobzakowski ${ }^{37}$.

It is highly likely that Bukowski, while working for the City Bureau for Urban Development, participated in various other spatial development projects, such as the one commissioned for Gutt's studio concerning the regulation of Góra Zamkowa (now Gediminas Hill) - a site of in-depth research and renovation in the $1930 \mathrm{~s}^{38}$.

33 „Sprawy urbanistyczne Wilna na posiedzeniu Magistratu” (Vilnius urban issues at the City Hall Meeting), in: Kurjer Nowogródzki, 1938, No. 95, p. 5.

34 Ibid.

35 Rasa Antanavičiūtè, „Urban Development in Vilnius during the Second World War”, in: Art and Artistic Life during the Two World Wars, Ed. Giedrè Jankevičiūtè, Vilnius: Lithuanian Culture Research Institute, 2012, p. 329.

36 „Lista rzeczoznawców urbanistycznych Związku Miast Polskich” (List of Urban Surveyors in the Association of Polish Cities), in: Biuletyn Urbanistyczny, 1938, No. 2, p. 62.

37 „Z Komisji Urbanistycznej Związku Miast Polskich” (At the Association of Polish Cities Urban Commission), in: Biuletyn Urbanistyczny, 1938, No. 3-4, p. 71.

38 K. P., „Kronika wileńska” (Vilnius chronicle), in: Biuletyn Historii Sztuki i Kultury, 1937, No. 1, pp. 100-101. More about the works in: Władysław Bortnowski, „Przegląd prac konserwacyjnych na Górze Zamkowej w Wilnie w latach 1930-1936" (Review of renovation works at the Castle Hill in Vilnius 1930-1936), in: Ateneum Wileńskie, 1938, No. 1, pp. 211-216. Jan Borowski and Engr. Władysław Paszkowski - the first Voivodeship Monument Conservator in Białystok after 1945 - were responsible for technical and architectural inspection. 


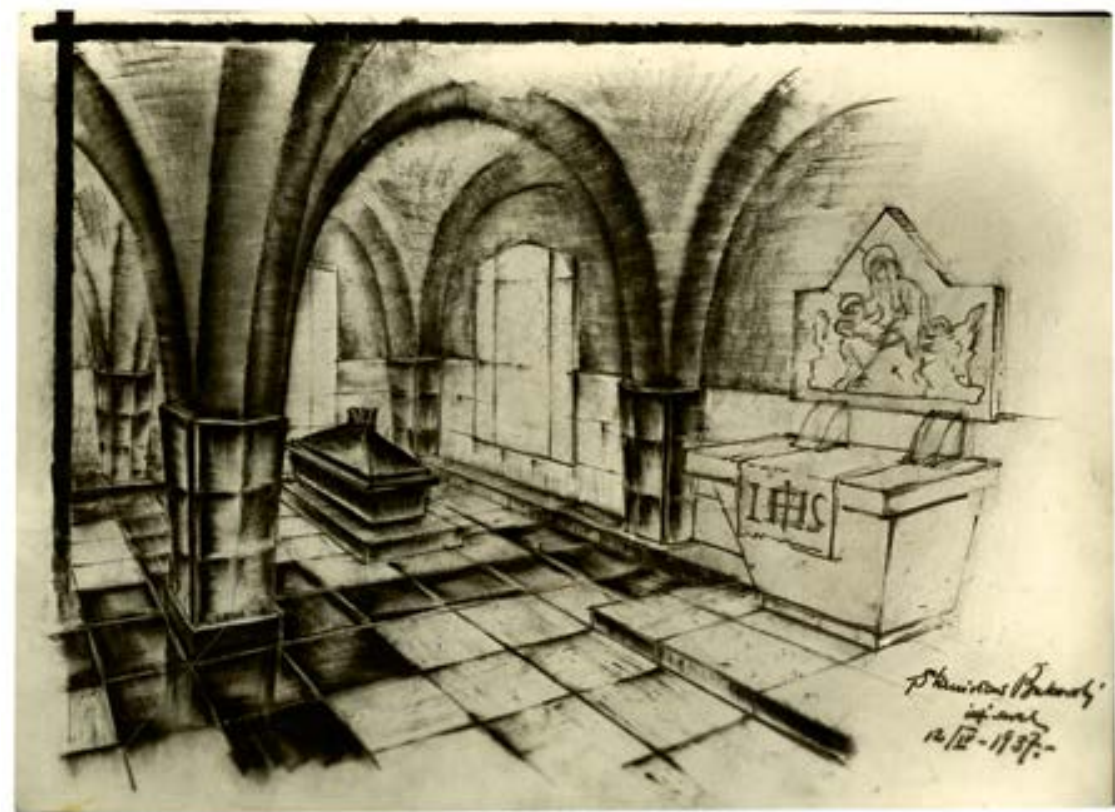

10.

A photograph presenting a visualisation of an interior design project of the royal mausoleum in Vilnius Cathedral by S. Bukowski, dated 12 April 1937,

Sleńdziński Gallery in Białystok collection
Stanisławo Bukowskio interjero dizaino vizualizacija Vilniaus arkikatedros mauzoliejaus projekte, $1937 \mathrm{~m}$. balandžio $12 \mathrm{~d}$.

Bukowski's most significant architectural project when he worked in Vilnius was the design of the interior of the royal crypts in the Vilnius Cathedral Basilica of St Stanislaus and St Vladislaus. The idea to create a mausoleum under Saint Casimir's chapel was formed after the city had been flooded in the spring of 1931 and a crypt with royal remains was discovered during the restoration works. The shell and core construction of the mausoleum based on the project by Prof. Juliusz Kłos was completed in February 1936. Soon after Kłos’s tragic death a special Conservation Commission on the royal mausoleum made a decision to invite tenders for an interior design project. On 16 March 1937 the Commission examined sketch designs by Stefan Narębski and Stanisław Bukowski, selecting the latter one [illus. 10]. The Ministry of Religious Affairs and Public Education adopted the mausoleum interior design project and on the request of Vilnius 


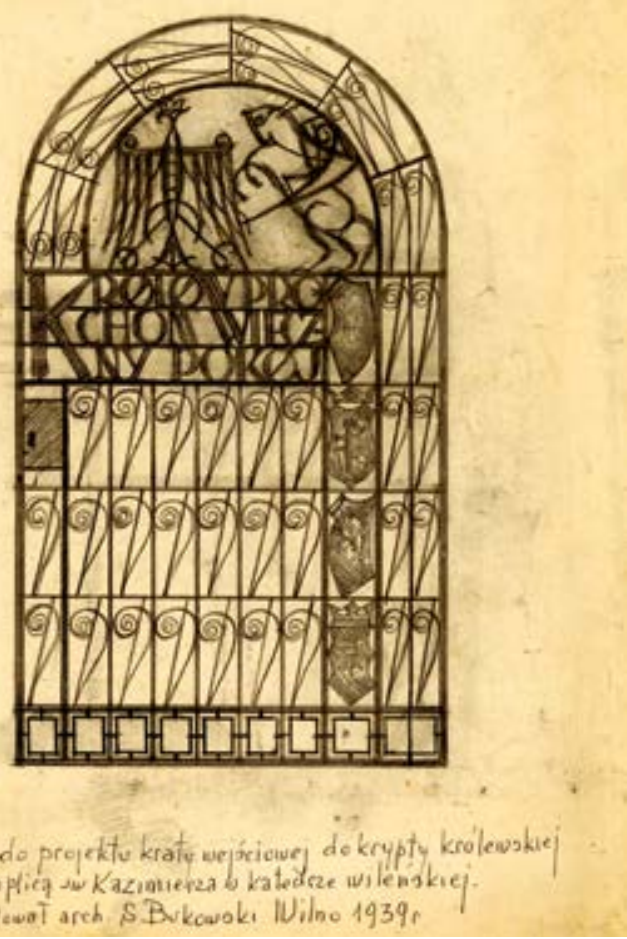

11.

A draft project of gates with a lattice to the royal mausoleum under Saint Casimir's Chapel in Vilnius Cathedral by S. Bukowski, 1939, Sleńdziński Gallery in Białystok collection

Stanisławas Bukowskis, Vilniaus arkikatedros karališkojo mauzoliejaus vartu grotelių projekto eskizas, 1939

conservator Ksawery Piwocki $\mathrm{PhD}$, it authorised the project designer to become an art director on 19 May 1937. The project introduced several artistically substantial changes in comparison to the design by Prof. Kłos. The modifications aimed at creating the effect of nine bays optically merging in order to give the impression of a consistent interior in contrast to the previous concept of a three-naved construction with four columns. The thickness of the columns was reduced and their cross section was changed from a square to an octagon, which gave an optical illusion of scaling down the columns. Altering the shape of the arches from a round curve to a parabolic one helped to form raised vaults. Apart from those modifications, Bukowski designed the elements of the mausoleum interior. A company from Vilnius run by A. Baranowska had managed to manufacture most of the designed 


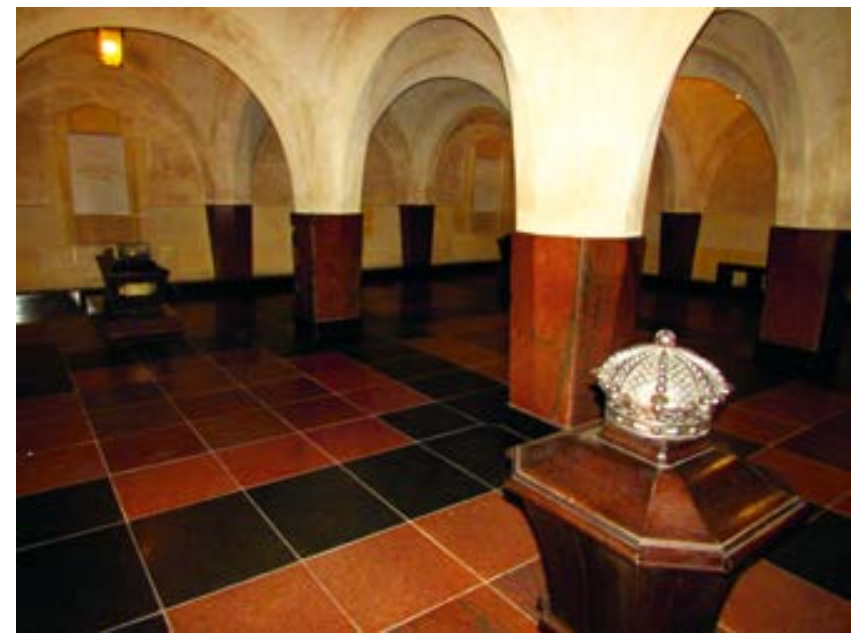

12.

The interior of the royal mausoleum in Vilnius Cathedral, as of October 2019, photo by Sebastian Wicher

Vilniaus arkikatedros karališkojo mauzoliejaus interjeras, $2019 \mathrm{~m}$. spalis

objects by the time the war began. Three coffins and an urn with a heart had been transferred to the crypt. Gates, lamps, plaques, sarcophagi, the mentioned urn, and a figure of Mother of God had not been fabricated. The three remaining objects were going to be put out to tenders ${ }^{39}$ [illus. 11, 12].

As for restoration works in the Basilica, there was an issue concerning the three wooden sculptures representing saints, which were located on the tympanum of the portico situated in front of the building. A suggestion was made to erect statutes made of reinforced concrete to replace the wooden ones, which were reintroduced in relation to a project by Wawrzyniec Gucewicz (Laurynas Gucevičius) - the author of the classicist reconstruction of the Basilica. Bukowski was in favour of the change and he expressed it on the pages of Stowo and Kurjer Nowogródzki. Jotha [Jerzy

39 A detailed description of the project and its implementation in: Piotr Śledziewski, „Mauzoleum Królewskie w Bazylice Wileńskiej” (Royal mausoleum in Basilica in Vilnius), in: Wilno, 1939, No. 2, pp. 107-119. Numerous articles in the local and national press, for example: „Konferencja w sprawie restauracji Bazyliki Wileńskiej” (Conference about the restoration of Basilica in Vilnius), in: Kurjer Wileński, 1937, No. 63, p. 2; M. Tr., „Mauzoleum Królewskie w Bazylice Wileńskiej” (Royal mausoleum in Basilica in Vilnius), in: Dziennik Wilenski, 1937, No. 176, p. 4; Józef Batorowicz, „Mauzoleum królewskie w Wilnie” (Royal mausoleum in Vilnius), in: Gazeta Polska, 1937, No. 182, p. 3 (the last two articles include copies of interior visualisation). In addition, the collection of the Sleńdziński Gallery in Białystok includes: photography of the interior visualisation by S. Bukowski (published in the article referred to above, p. 115), „Projekt wnętrza mauzoleum królewskiego w Katedrze Wileńskiej” (1937) (Project of the royal mausoleum interior in Vilnius Cathedral), „Projekt posadzki w mauzoleum królewskim w Katedrze Wileńskiej” (1937) (Floor design in the royal mausoleum in Vilnius Cathedral), and „Szkic do projektu kraty wejściowej do krypty królewskiej pod kaplicą św. Kazimierza w katedrze wileńskiej” (1939) (Draft project of a lattice gate to the royal crypt under Saint Casimir's chapel) - all published in: Sebastian Wicher, op. cit., pp. 33-34. 
Hoppen], disagreed with Bukowski over the matter. He was the proponent of replacing the statues with smaller ones made of limestone ${ }^{40}$.

As the representative of the City Hall, Bukowski was often invited to participate in artistic commissions and competition committees. In February 1937 the City Bureau for Urban Development announced a decision to change the location of the planned Adam Mickiewicz monument from Orzeszkowa Square to the Bernardine Garden due to public transport issues. The final decision was reached at a meeting of the artistic commission of the Monument Construction Committee, which included S. Bukowski, L. Sleńdziński, J. Hoppen, M. Limanowski, J. Borowski, S. Narębski, R. Gutt, J. Kobzakowski, K. Piwocki, J. Bułhak, S. Lorentz, T. Tołwiński, T. Breyer, H. Kuna and M. Salewicz ${ }^{41}$. In November 1937 there was an announcement about an architectural competition for a draft design for a Lombard House building of the Municipal Savings Bank in Vilnius near a newly designed Dąbrowski St. (now A. Smetonos St.), between Mickiewicz St. (now Gedimino Ave) and Portowa St. (now Pamėnkalnio St.). Bukowski represented the City Bureau for Urban Development as a member of the competition panel ${ }^{42}$. A four-storey construction based on a winning project by Irena Heilmanowa was completed at the end of 1939 and has been preserved to this day ${ }^{43}$. Bukowski was a member of various organisations and associations, for instance, the board of the Air and Chemical Defense League ${ }^{44}$ or the Executive

40 Stanisław Bukowski, „List do Redakcji” (A letter to the editorial office), in: Stowo, 1937, No. 20, p. 6 and Kurjer Nowogródzki, 1937, No. 20, p. 6 and also a polemical article in: Jotha, „Jeszcze o figurach świętych na Bazylice Wileńskiej” (More about the statues of saints on the Basilica in Vilnius), in: Stowo, 1937, No. 21, p. 6 and Kurjer Nowogródzki, 1937, No. 21, p. 6.

41 (e), „Gdzie stanie pomnik A. Mickiewicza? Plac Orzeszkowej wykreślony z rachuby” (Where will the A. Mickiewicz monument be built? Orzeszkowa Square is off the list), in: Dziennik Wileński, 1937, No. 41, p. 5; „Pomnik A. Mickiewicza stanie w ogrodzie po-bernardyńskim” (A. Mickiewicz Monument in the former Bernardine Garden), in: Dziennik Wilenski, 1937, No. 48, p. 5.

42 Program i warunki konkursu powszechnego S.A.R.P. XCI na projekt szkicowy Zaktadu Zastawniczego Komunalnej Kasy Oszczędności w Wilnie ogłoszony na zlecenie Komunalnej Kasy Oszczędności miasta Wilna (The Programme and Regulations of the S.A.R.P. [Association of Polish Architects] XCI General Competition for a Draft Project of a Lombard House of Municipal Savings Bank in Vilnius announced by Municipal Savings Bank in Vilnius), Wilno: Stowarzyszenie Architektów Rzeczypospolitej Polskiej Oddział w Wilnie, 1937, p. 7.

43 „Lombard w nowym gmachu” (The New Building of Lombard House), in: Kurjer Wileński, 1939, No. 226, p. 4; Małgorzata Dolistowska, „Miłe miasto” między tradycją a awangardą. Architektura Wilna w dwudziestoleciu międzywojennym - zarys problematyki" (A nice city - between tradition and avant-garde. The architecture of Vilnius in the interwar period - an overview), in: Stan badan nad wielokulturowym dziedzictwem dawnej Rzeczypospolitej (The State of Research on Multicultural Heritage in the Old Commonwealth), vol. VIII, Ed. Wojciech Walczak, Karol Łopatecki, Białystok: Instytut Badań nad Dziedzictwem Kulturowym Europy, 2017, p. 131.

44 „Dorobek wileńskiego LOPP” (The Legacy of Air and Chemical Defense League in Vilnius), in: Kurjer Wileński, 1937, No. 96, p. 2. 


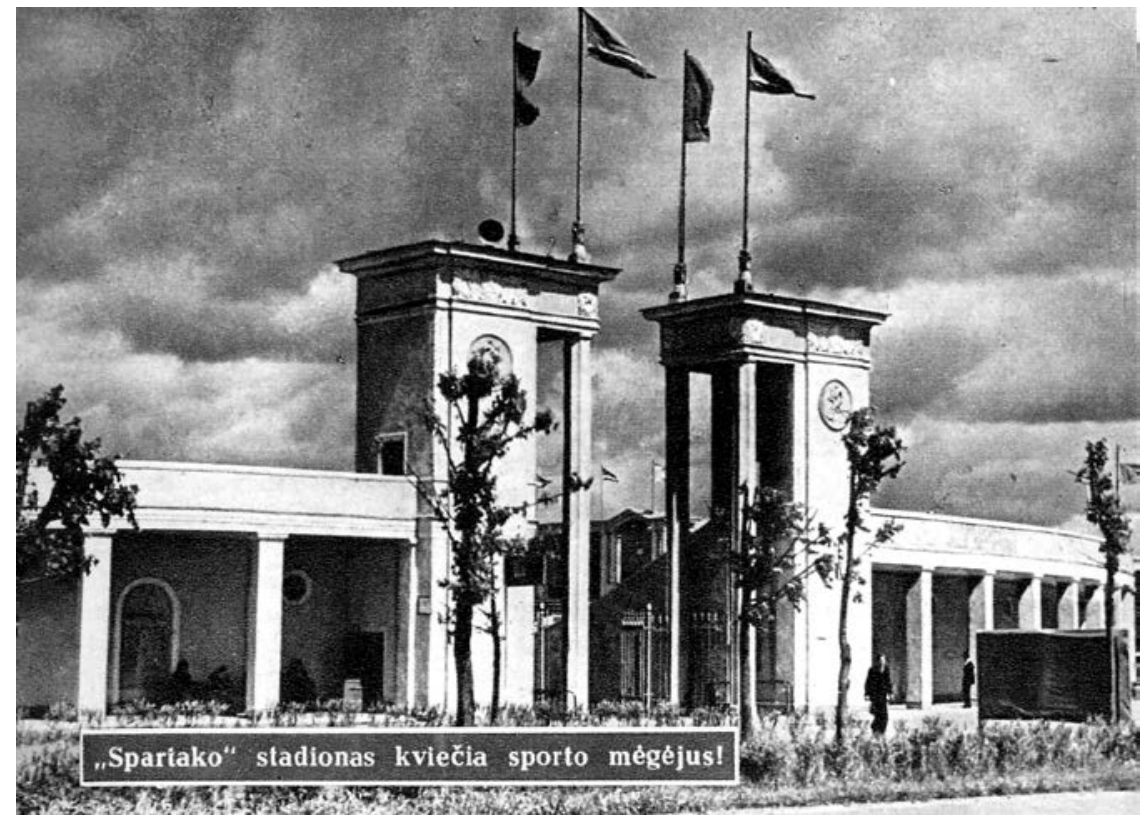

13.

The entrance gate to the stadium in Pióromont (now Piromontas) with the changes introduced by the architect Viktor Anikin, a postcard from the 1950s
Piromonto stadiono pagrindiniai vartai, atlikus architekto Viktoro Anikino pakeitimus

Committee of 25th Anniversary of Vilnius Legions Division, which included a Marshall Józef Piłsudski Soldier's Home Construction Section in Vilnius ${ }^{45}$.

In 1937 the Municipal Sports Committee contracted the architect R. Gutt to create a project for a Sports Park with bathing lake, indoor swimming pool and Sports House near the sports field at the Physical Education Centre in Pióromont (now Piromontas). The construction work started in the first half of 1937, lasted throughout 1938 and was to be terminated in the summer of the following year. However, the investment was interrupted by the war. Eventually, a two-storey covered stand for 2,000 spectators, cloakroom, washroom, gym, kitchen, storage facility and offices of the PE Centre were built according to Gutt's project ${ }^{46}$. The monumental

45 „Komitet Obywatelski obchodu 25-lecia wileńskiej Dyw. Legionowej” (Citizens' Commiittee of $25^{\text {th }}$ Anniversary of Vilnius Legions Division), in: Kurjer Wilensski, 1939, No. 203, p. 2.

46 „Co się ma stać w sporcie wileńskim” (What is to happen in Vilnius Sport?), in: Dziennik Wileński, 1937, No. 225, p. 4; Romuald Gutt, Ed. Olgierd Czerner, Warszawa: Arkady, 1968, p. 42; Waldemar Wołkanowski, „Zanim zniknie „Žalgiris”, czyli jak powstawał stadion w Wilnie” (Before 'Žalgiris' is gone, or the story behind the construction of the stadium in Vilnius), in: Wilnoteka, [online], 17 November 2017, [cited 2019-11-29], http://www.wilnoteka.lt/artykul/zanim-znikniequotzalgirisquot-czyli-jak-powstawal-stadion-w-wilnie. 
entrance gate to the stadium, on the other hand, was based on Stanisław Bukowski's project ${ }^{47}$ [illus. 13]. In the post-war period the stadium (until recently Žalgiris stadium, Rinktinès St.) was redeveloped and rebuilt by, inter alia, a Belarusian architect Viktor Anikin (until recently he was considered the sole creator of the stadium $)^{48}$. The neglected structure was taken apart in 2016 and currently a hotel, a conference centre and office buildings are being built in that location.

A comprehensive school building in Lipówka (now Liepkalnis) at 18 Belina-Prażmowski St. (now Liepkalnio St. 18) was yet another of Gutt's projects that Bukowski was involved in. It was designed in 1936 and built in 1938-3949 [illus. 14]. According to an expert researcher into Vilnius architecture, Prof. Edmund Małachowicz:

\footnotetext{
The school building was an example of a modern and functional solution, including the interior; its design corresponded perfectly with the undulating woody landscape of the surrounding area. Just like its twin design - a school in Antokol [based on a project by Stefan Narębski, - S. W.], it is made of two blocks arranged into a horseshoe shape and connected in the middle. The connector linked to the hilly terrain with a concrete bridge also had a decorative garden at the front. The south wing gable wall was particularly outstanding - covered in mosaic stones from granite boulders. ${ }^{50}$
}

47 Edmund Małachowicz, „Architektura dwudziestolecia międzywojennego w Wilnie” (The architecture of interwar period in Vilnius), in: Studia $i$ materiaty do teorii $i$ historii architektury $i$ urbanistyki (Studies and materials on the theory and history of architecture and urban planning), Warszawa: Państwowe Wydawnictwo Naukowe, 1989, vol. XVII: Architektura $i$ urbanistyka w Polsce w latach 1918-1978 (Architecture and urban planning in Poland in 1918-1978), Ed. Wojciech Kalinowski, p. 136.

48 Vilnius 1900-2013. A guide to the city's architecture, Ed. Julija Reklaitè, Rūta Leitanaitè, Vilnius: Architektūros Fondas, 2013, p. 100.

49 Edmund Małachowicz, op. cit., p. 135; Vilnius 1900-2013, pp. 68-69; Michał Pszczółkowski, Kresy nowoczesne. Architektura na ziemiach wschodnich II Rzeczypospolitej 1921-1939 (Modern Eastern Borderlands. The architecture in the Eastern Territory of the Second Polish Republic 1921-1939 ), Łódź: Księży Młyn, 2016, pp. 230-232; Małgorzata Dolistowska, op. cit., pp. 146-147; Wilno XX-XXI. Przewodnik architektoniczny (Vilnius XX-XXI. Architectural Guide), Ed. Marija Drèmaite, et al., Warszawa: Fundacja Centrum Architektury, 2019, pp. 82-83.

50 Edmund Małachowicz, op. cit., p. 135.

51 Izabela Suchocka, Placyda Bukowska (1907-1974). W stulecie urodzin (Placyda Bukowska (1907-1974). 100th Birthday Anniversary), Białystok: Galeria im. Sleńdzińskich w Białymstoku, 2007, p. 45. 


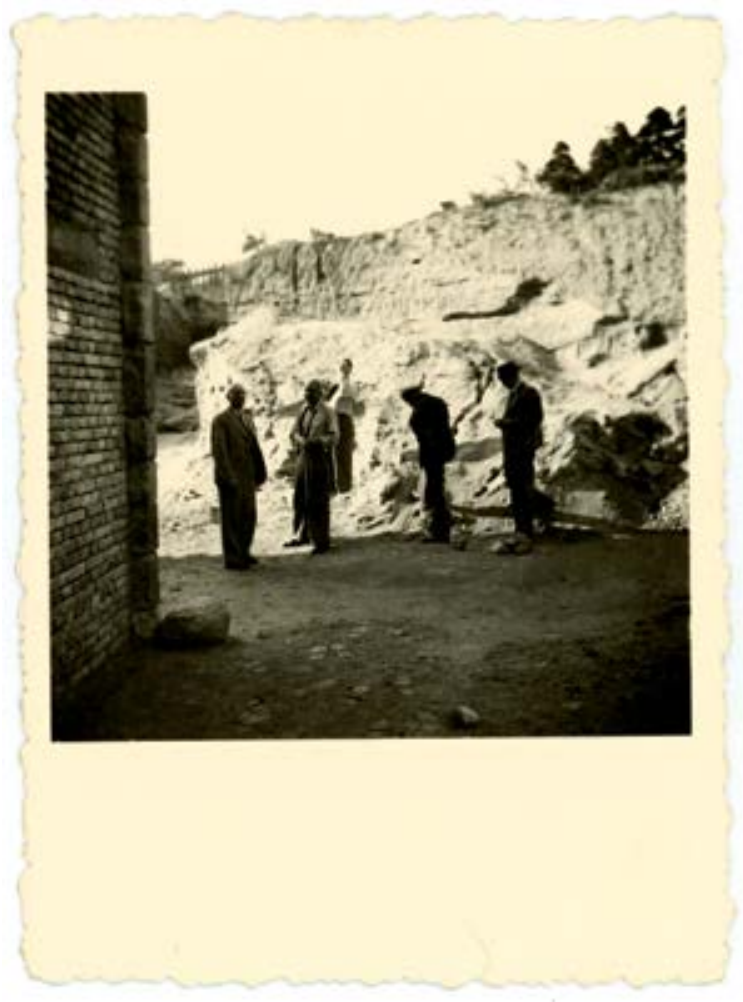

\begin{abstract}
14.
On the construction site of the school in Lipówka, from the left: Tadeusz Tołwiński, Romuald Gutt, unidentified person, Stanisław Bukowski, unidentified person, late 1930s, Sleńdziński Gallery in Białystok collection

Liepkalnio mokyklos statybu aikštelèje, iš kairès: Tadeuszas Tołwińskis, Romualdas Guttas, nežinomas asmuo, Stanisławas Bukowskis, nežinomas asmuo, XX a. 4 deš. pab.
\end{abstract}

That wall, designed by Bukowski's wife - Placyda Siedlecka-Bukowska $^{51}$, is characteristic to highly textural facades popular in the architecture of 1930s of 20th century [illus. 15]. A superb renovation of the building took place in 2011-2012 and it was based on the projects of Unitectus studio in Vilnius ${ }^{52}$ [illus. 16].

In the context of Stanisław Bukowski's architectural activity, there is a need to clarify the authorship of two buildings: the apartment for M. Deul company staff at 14 Dąbrowski St. (now A. Jakšto St. 14) and a villa at 5 Kamienna St. (now Akmenų St. 5) [illus. 17, 18]. Both are mentioned by Edmund Małachowicz who - based on Bukowski's account (who mentioned it in correspondence which is in Joanna Łempicka's collection) included the information in an article on interwar architecture in Vilnius. Nevertheless, he did not explain directly whether Bukowski designed or

52 „Liepkalnio“ gimnazijos rekonstravimas (Reconstruction of Liepkalnis Gymnasium), in: Unitectus architektų grupè, [online], [cited 2019-11-29], http://www.unitectus.lt/lt/project/liepkalniogimnazijos-atnaujinimas-vilnius.html. 


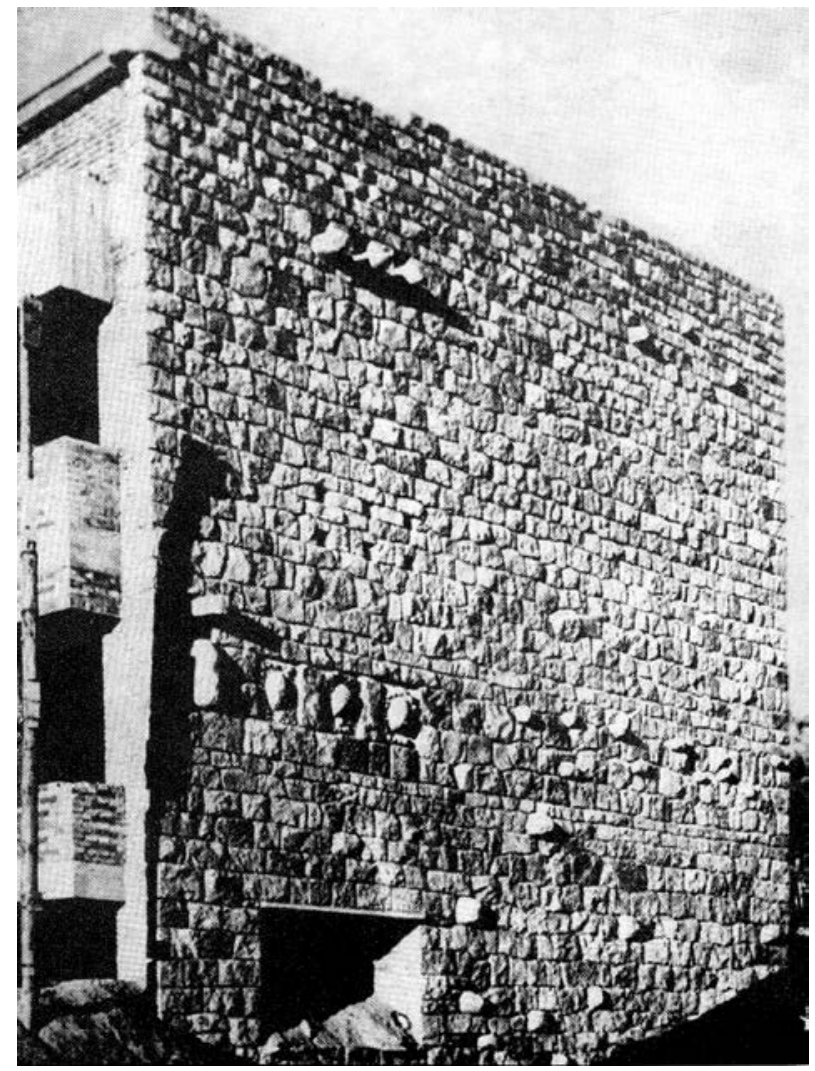

15.

The east wing gable wall in Lipówka with mosaic stones by Placyda Siedlecka-Bukowska, late 1930s, photograph by Stanisław Bukowski, in: Romuald Gutt, Ed. Olgierd Czerner, Warszawa 1968

Liepkalnio mokyklos rytinio sparno frontono siena su Placydos SiedleckosBukowskos mozaika, XX a. 4 deš. pab.

co-designed those buildings $\mathrm{s}^{53}$. On the other hand, authors of the guidebook Vilnius 1900-2013. A guide to the city's architecture points out that the project of the first building was attributed to S. Bukowski and Moses Cholem in 1940 [p. 84] and the other one was designed by Bukowski for Engr. Witold Maksimowicz, who resided at 3 Kamienna St. ${ }^{54}$. The case requires further research. Interestingly, the president of Vilnius, Dr. Wiktor Maleszewski, used to live on the very same street at number 7 .

Bukowski was involved with the Northern Trade Fair Association. In the years 1928-1939 the fairs constituted a periodic exhibition of Polish and foreign trade. Their aim was to make Vilnius the centre of commerce in relations between Poland and countries in the east especially the Baltic States. During the first years, the trade fair grounds were located in the former 

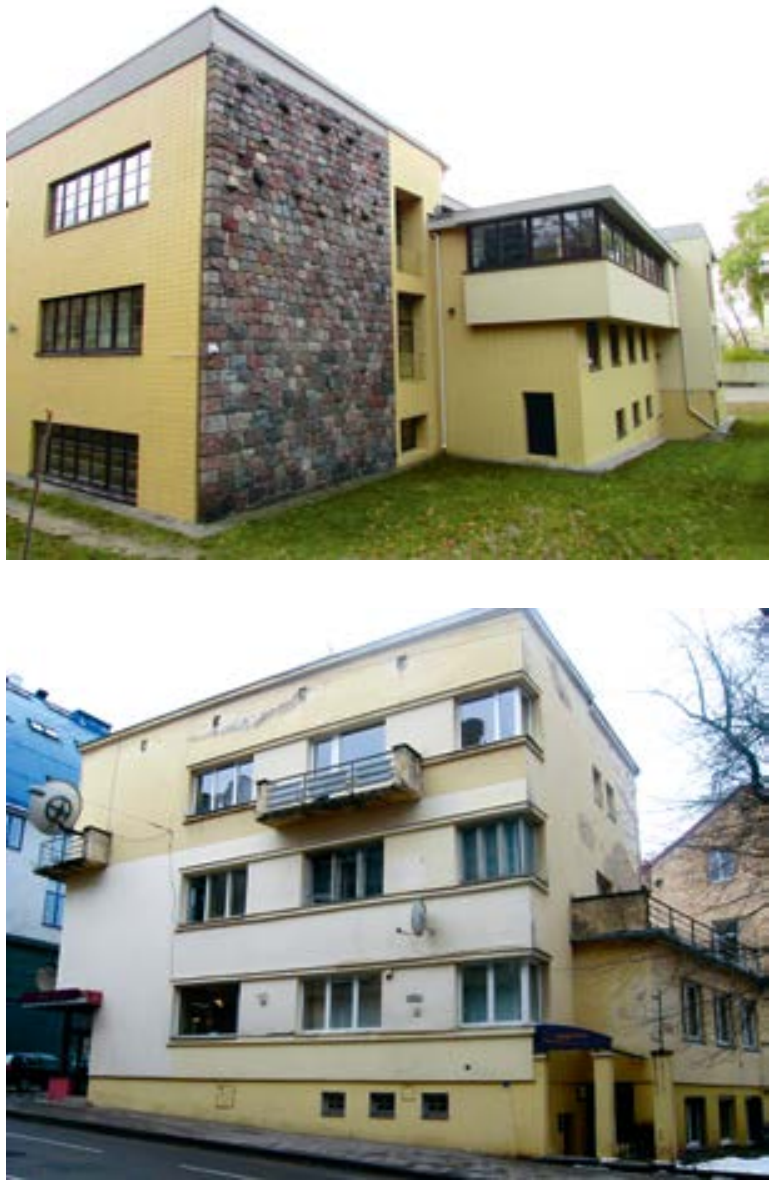

16.

School in Lipówka (now

Vilniaus Liepkalnio Mokykla at Liepkalnio g. 18) as of October 2019, photograph by Sebastian Wicher

Liepkalnio mokykla (dab. Vilniaus Liepkalnio mokykla, Liepkalnio g. 18), 2019 m. spalis

17.

An apartment of the M. Deul company at 14 Dąbrowskiego St (now A. Jakšto g. 14), as of March 2009, photograph by Izabela Suchocka

Apartamentai M. Deul kompanijos darbuotojams (dab. A. Jakšto g. 14), $2009 \mathrm{~m}$. kovas

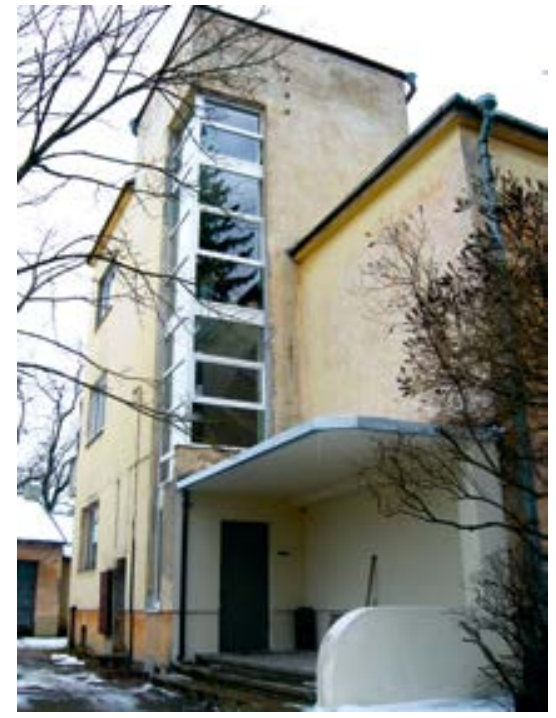

18.

Engr. Witold Maksimowicz's villa at 5 Kamienna St (now Akmenų g. 5), as of March 2009, photograph by Izabela Suchocka

Graverio Witoldo

Maksimowicziaus vila (dab.

Akmenu g. 5), 2009 m. kovas 
Bernardine Garden and the converted military garages became pavilions. Additionally, there were stands in the Summer Theatre of the Fine Arts Faculty at Stephen Báthory University (now Vilnius University) as well as in the School of Industry and Commerce. The Northern Trade Fair Association was founded on 16 January 1937 in order to organise the following trade fair, which up until then had been the responsibility of the Vilnius local authorities. For that purpose, the association had purchased a seven-ha plot from the city in the area between Legionów, Wiwulski and Szeptycki Streets (now Savanorių Ave., A. Vivulskio St. and T. Ševčenkos St. accordingly) and erected several exhibition pavilions and modern facilities ${ }^{55}$. S. Bukowski was the chairman of the Technical and Artistic Commission within the association. He provided advice on matters concerning the development of the fairgrounds, promotion, equipment, decorations, shows and events, publishing etc. ${ }^{56}$.

Alongside the projects, Bukowski was also engaged in conservation work outside Vilnius. In the 1930s the stucco interior of the 13th-century St. Michael the Archangel parish church in Michaliszki (now Hrodna Region in Belarus) was being renovated under the supervision of conservator Stanisław Lorentz and a painter Jerzy Hoppen. S. Bukowski was a member of the artistic committee established on 10 September 1938 by the Church Restoration Committee together with Piotr Śledziewski PhD, Władysław Muzolff and a restoration work manager, Jan Peksza ${ }^{57}$ [illus. 19].

55 More about the history of the Fair in: „Wznowienie Targów Północnych” (Revival of the Northern Trade Fair) by Kazimierz Wójcicki, in: Nasze Sprawy, 1938, No. 9, pp. 1-2; Targi Pótnocne w Wilnie. Czym byty - czym sa - czym maja być (Northern Trade Fair in Vilnius. What they were - what they are - what they will be), Wilno: Towarzystwo Targów Północnych w Wilnie, 1939; Aleksander Srebrakowski, „Targi Północne w Wilnie 1928-1939” (Northern Trade Fair in Vilnius 1928-1939), in: Wokót historii i polityki. Studia z dziejów XIX i XX wieku dedykowane Profesorowi Wojciechowi Wrzesinskiemu w siedemdziesiąta rocznice urodzin (On history and politics. Studies of 19th and 20th century dedicated to Professor Wojciech Wrzesiński on his seventieth birthday), Ed. Stanisław Ciesielski, et al., Toruń: Wydawnictwo Adam Marszałek, 2004, pp. 781-787, Michał Pszczółkowski, op. cit., pp. 233-237; Vilnius $X X-X X I$, p. 81. There are numerous articles in the Vilnius press on the subject.

56 „Protokół 2 posiedzenia Sądu Konkursowego na Targi Północne w Wilnie” (The minutes of the 2nd meeting of Competition Panel for the Northern Trade Fair in Vilnius) and „Protokół ostatecznego posiedzenia Sądu Konkursowego na Targi Północne w Wilnie” (The minutes of the final meeting of the Competition Panel for the Northern Trade Fair in Vilnius), in: Komunikat SARP, 1938, No. 4-5, pp. 6-9; Targi Pótnocne w Wilnie (Northern Trade Fair in Vilnius), p. 10.

57 „Materiały do dziejów sztuki sakralnej na ziemiach dawnej Rzeczypospolitej” (Materials on the history of religious art in the former Polish Commonwealth territory), in: Kościoty $i$ klasztory rzymskokatolickie dawnego województwa wileńskiego (Roman Catholic churches and monasteries in the former Vilnius Voivodeship), Kraków: Międzynarodowe Centrum Kultury, 2005, pt III, vol. I, Ed. Maria Kałamajska-Saeed, pp. 154-156. 


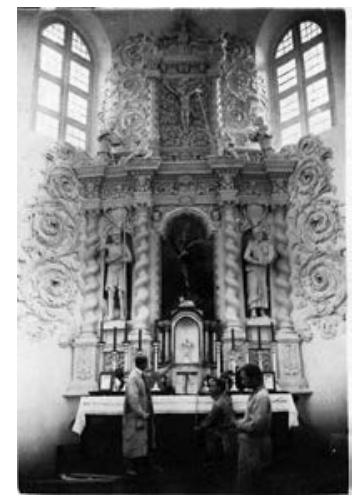

19.

The main altar in St. Michael the Archangel parish church in Michaliszki during conservation works, 1938, photograph by Adam Animucki, retrieved from: www.radzima.org/pl/object-photo/1406.html [cited 2019$12-10]$

Pagrindinis Šv. Mykolo arkangelo bažnyčios Mikailiškèse [Michaliszki] altorius konservavimo metu, 1938

The outbreak of World War II inhibited many of the planned and ongoing investments of Vilnius City Hall. During the first days of September 1939, the city officials informed the citizens in the local press about individuals who could give expert advice on airborne defence. They listed Stanisław Bukowski (who resided at 2 Dominikańska St., room No. 6) and other staff members of the Department of Building Inspection such as Stefan Narębski, Jan Borowski, Edward Machnacz, Edmund Nowicki and Irena Heilmanowa ${ }^{58}$.

Despite the military actions and abrupt changes in the status of Vilnius and its national identity, the City Bureau for Urban Development continued its work ${ }^{59}$. When the city authorities had regained control over Vilnius, the name of the Bureau was changed to Vilnius City Development Directorate. There was staff reshuffling too. First of all, in November 1939 R. Gutt left the city to be replaced by Vytautas Landsbergis-Žemkalnis, a renowned Lithuanian architect, and a graduate from Regia Scuola Superiore di Architettura in Rome. He remained in charge, with a short break, until February 1943. Bukowski and Kobzakowski continued to work alongside their colleagues Leszek T. Dąbrowski, Jan Peksza, Kazimierz Biszewski, Zbigniew Czech, Juliusz Dumnicki, Wiktor Espenhan and others. The reason for the presence of Polish urban planners in the Directorate was purely practical. Not only did they demonstrate the knowledge of the city

58 „Poradnia do spraw O. P. L.-Gaz.” (Airborne and antigas defence information bureau), in: Goniec Poranny, 1939, No. 168, p. 4; „Poradnia do spraw obrony przeciwlotniczej” (Airborne and antigas defence information bureau), in: Gazeta Wilenska, 1939, No. 242, p. 3.

59 The activity of the Bureau in that period is analysed in: Rasa Antanavičiūtè, Menas ir politika, p. 239-279. 


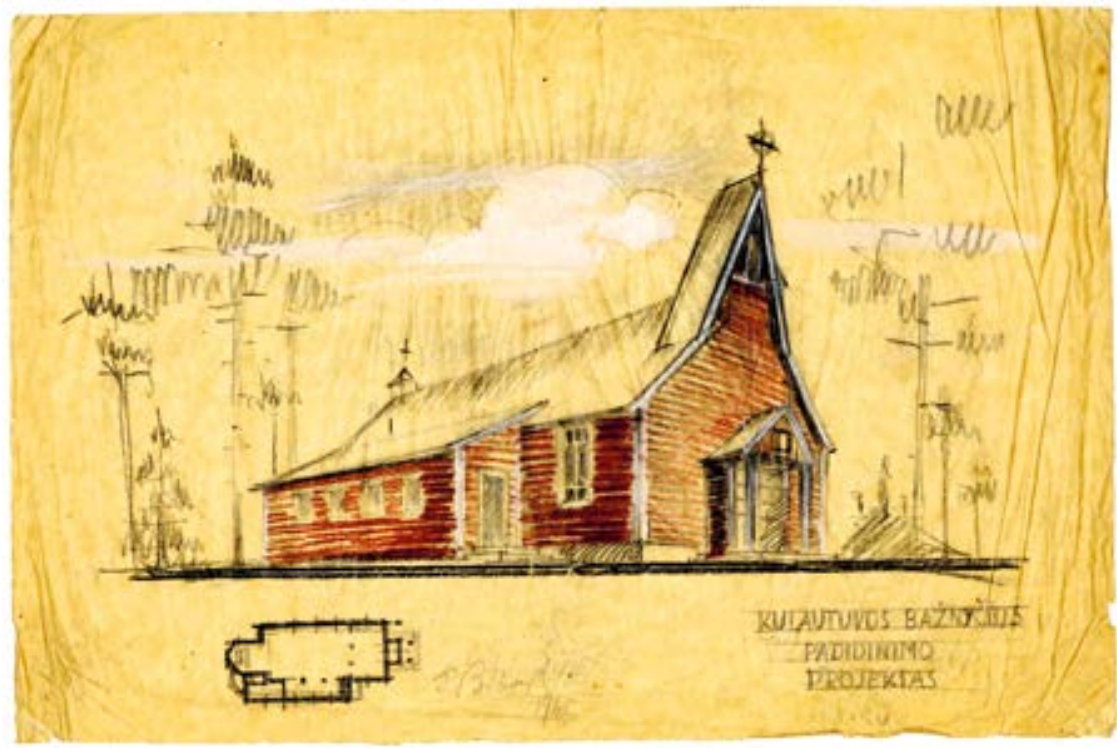

20.

A design for the conversion of St. Peter's chapel into the Church of Our Lady in Kulautuva by Stanisław Bukowski, 1940, Sleńdziński Gallery in Białystok collection
Stanisławas Bukowskis, Šv. Petro koplyčios pavertimo Švč. Mergelès Marijos bažnyčia Kulautuvoje projektas, 1940

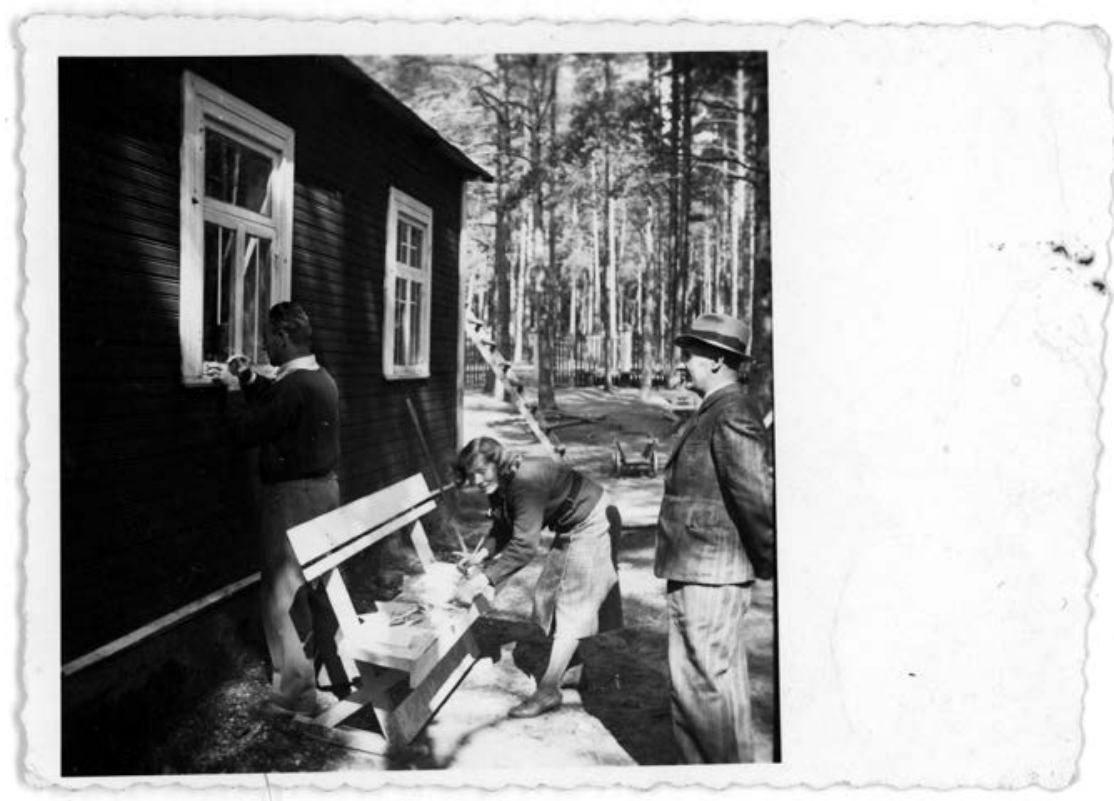

21.

Placyda Siedlecka-Bukowska with unidentified men near the Church of Our Lady in Kulautuva, 1940, Sleńdziński Gallery in Białystok collection
Placyda Siedlecka-Bukowska kartu su nenustatytais asmenimis šalia Švč. Mergelès Marijos bažnyčios Kulautuvoje, 1940 


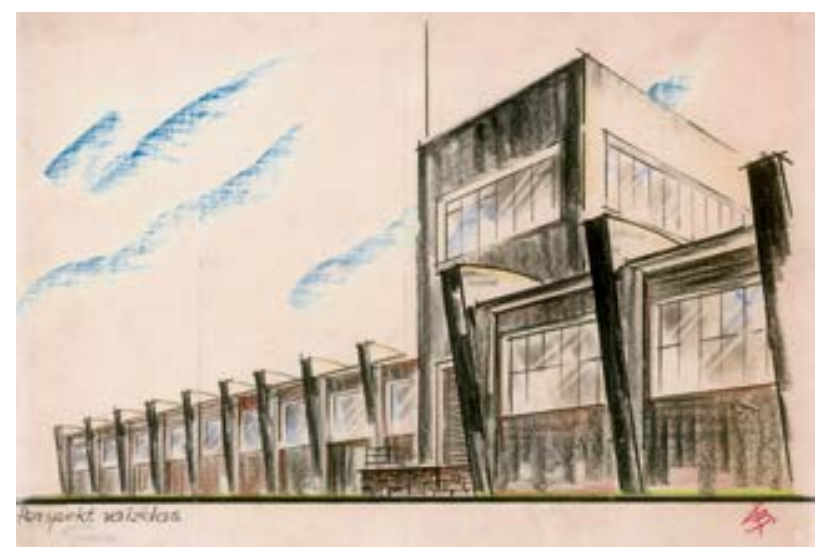

22.

A competition design of a swimming pool in Vilnius by S. Bukowski, 1940, from the collection of the regional department of the National Archives in Vilnius, in: (Ne)matomas Vilnius: tarpukario dailès ir architektūros pavidalai: Parodos katalogas, Vytauto Kasiulio dailès muziejus / (In)visible Vilnius: Shapes of Interwar Art and Architecture: Exhibition catalogue, Vytautas Kasiulis Art Museum, Vilnius: Vilniaus dailès akademijos leidykla, 2018, p. 74-75
Stanisławas Bukowskis, Konkursinis baseino Vilniuje projektas, 1940

topography, but they had also completed numerous projects involving the city regulation ${ }^{60}$. Bukowski worked there up to 1 January $1940^{61}$. He probably lived on his personal savings for the following four months. It was not until 11 April 1940 that the architect was contracted by the Executive Committee of Kaunas County to work on planning and designing Kulautuva resort near Kaunas; he worked on it until 1 December $1940^{62}$. It was at that time that he also created a project that would transform a wooden chapel into the Church of Our Lady in Kulautuva ${ }^{63}$ [illus. 20, 21]. The small temple

60 Rasa Antanavičiūtè, „Urban Development”, p. 324.

61 NLP, [Materiały dotyczące biografii Stanisława Bukowskiego, jego działalności zawodowej i twórczości], f. Rps akc. 12134: A copy of the authorising document No. 3267/BU by the Executive Committee in Vilnius dated to 7 May 1941, no pagination.

62 NLP, [Materiały dotyczące biografii Stanisława Bukowskiego, jego działalności zawodowej i twórczości], f. Rps akc. 12134: A copy of the authorising document No. 328 by the District Executive Committee of Kaunas County dated to 15 January 1941, no pagination.

63 Sleńdziński Gallery in Białystok, „Kulautuvos bažnyčios padidinimo projektas“ (Kulautuva Church Increase Project), S. Bukowski, 1940, unsigned. In the collection of Joanna Łempicka from Białystok there is a wooden polychrome sculpture in the form of a Latin cross with a representation of the crucified Jesus with an inscription in Polish written on its base in Bukowski's handwriting: This crucific [illegible] from Samogitia / was presented in 1940 by Fr A. Miksza in Kulautuva near Kaunas / to Engr. S. Bukowski for conversion of a chapel into a church. Short history of the church in: Kazys Misius, Romualdas Šinkūnas, Lietuvos kataliku bažnyčios: Žinynas (The Catholic Church of Lithuania: A Handbook), Vilnius: Pradai, 1993, p. 142. Gallery collection includes a watercolour painting of an idyllic landscape of Kulautuva done in 1940 and signed by Bukowski. 
with an expressive facade burnt down in a fire in 2012. A brick church based on Darius Jakubauskas's design is being built in the same location.

On 15 June 1940 the Soviets established the Lithuanian Soviet Socialist Republic. The former City Bureau for Urban Development became the City Construction Department of the Vilnius Executive Committee. Urban planners could continue their work on the general development plan of Vilnius, however, in compliance with the values of socialist realism. In September 1940, the Committee recommenced working on the regulation of the train station square, which required some of the neighbouring buildings to be demolished in order to widen the arterial road ${ }^{64}$.

In 1940 Bukowski participated in the competition for a design project of a covered swimming pool in Tartaki St. in Vilnius (now the area within the Neris River bend, J. Jasinskio St. and Geležinio Vilko St. ${ }^{65}$ [illus. 22]. It is likely that Bukowski completed many such projects at that time, for instance a project of a kiosk ${ }^{66}$ [illus. 23].

In January 1941 Bukowski was directed to a gymnasium in Trakai by the City People's Commissar in Vilnius ${ }^{67}$, but his function there remains unknown. In the middle of April, Bukowski was appointed by Valerijonas Knyva, the LSSR commissar for Municipal Economy, to be the deputy head in the City Council for Measurement and Planning in Vilnius with a monthly salary of 1,000 roubles $^{68}$. There is an interesting narrative by Andrzej Szperl

64 Rasa Antanavičiūtè, Menas ir politika, pp. 248-253.

65 The project is in the regional department of the National Archives in Vilnius (Vilniaus regioninis valstybės archyvas) and it was on display from 12 July to 16 September 2018 on an exhibition organised by the Vilnius Academy of Arts in Vytautas Kasiulis Art Museum, exhibition curators: Algė Andriulytė, Rasa Butvilaitė, Ilona Mažeikienė. See: (Ne)matomas Vilnius: tarpukario dailes ir architektūros pavidalai: Parodos katalogas, Vytauto Kasiulio dailès muziejus / (In)visible Vilnius: Shapes of Interwar Art and Architecture: Exhibition catalogue, Vytautas Kasiulis Art Museum, Vilnius: Vilniaus dailès akademijos leidykla, 2018, pp. 74-75.

66 In previous years an Ozalid print of the project was donated to the collection of the Sleńdziński Gallery in Białystok by Lech Narębski from Torun (Stefan Narębski's grandson). The authorship of the copy had been wrongly ascribed to Narębski. The architect's signature and the year 1941 written in pencil are visible near the edge of the drawing and Bukowski's monogram is next to the drawing. The project was published in: Stefan Narębski (1892-1966) - architekt, konserwator, profesor (Stefan Narębski (1892-1966) architect, conservator, professor), Ed. Marek Rubnikowicz, Toruń: Muzeum Okręgowe w Toruniu, 2017, p. 60. Was it another competition project and when was it created? It remains unknown, the matter requires further research.

67 NLP, [Materiały dotyczące biografii Stanisława Bukowskiego, jego działalności zawodowej i twórczości], f. Rps akc. 12134: Authorising document of City People's Commissar in Vilnius dated to 20 January 1941, no pagination.

68 NLP, [Materiały dotyczące biografii Stanisława Bukowskiego, jego działalności zawodowej i twórczości], f. Rps akc. 12134: Order No. 20 of City People's Commissar in Vilnius, dated 15 April 1941, no pagination. 


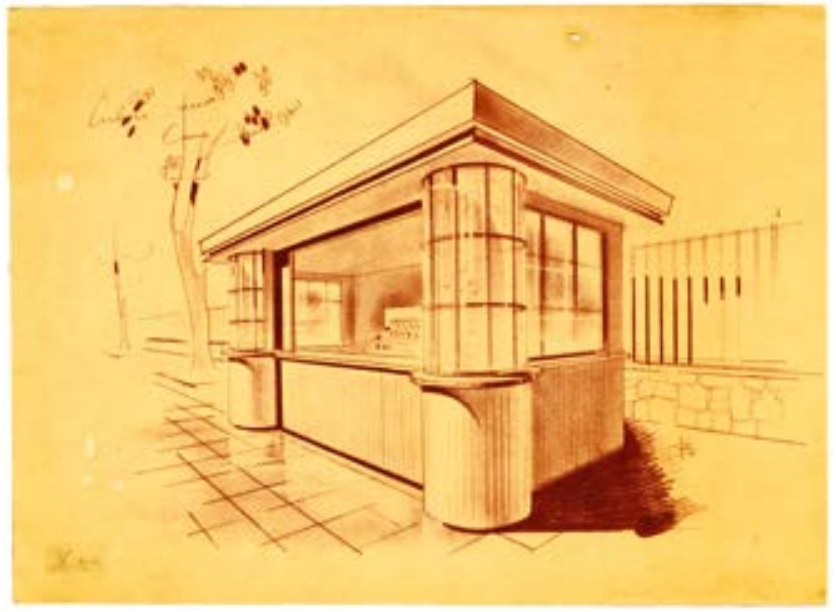

23.

Design for a kiosk by S. Bukowski, 1941, Sleńdziński Gallery in Białystok collection Stanisławas Bukowskis, Kiosko projektas, 1941

quoted in a book by a Polish poet and writer Jan Maria Gisges entitled Wywoływanie duchów:

My brother and I escaped from Beinarova to Kaunas on 21 February 1941. We were hiding in an apartment of a Polishman, Montwiłł - a Lithuanian Supreme Court Judge and from there we managed to contact the senior engineer at a construction trust company - Engr. Bukowski, who hired us among five thousand people working on the construction of an embankment regulating the area where Neris flows into the Nemunas River [it is located in Kaunas - S.W.]. In May I changed jobs again thanks to Engr. Bukowski, who transferred me to a pump station and water retainers, which had been built according to his designs. ${ }^{69}$

At this stage it is impossible to state clearly if those memories refer to architect Bukowski. The difficulties stem from the fact that there was another architect in Kaunas at that time with an identical name Stanisław Bukowski (1903-1977). He was a Kaunas University graduate, who created several projects, including the conversion of a tenement house belonging to Doctor Kowalski into a boarding school for Polish students at the Kaunas University, the Longin Juchniewicz's (Lionginas Junknevičius) tenement 
house at 24 E. Ožeškienès St. in Kaunas (1937), and together with Wacław Michniewicz the Church of Christ the King in Tyrkszle (now Tirkšliai) $(1937)^{70}$. Therefore, the issue requires further research.

On 21 June 1941 Vilnius was occupied by the Germans who, just as the Lithuanians and Soviets before them, allowed the urban office to continue its work, but changed its name to Stadtbauamt ${ }^{71}$. The following three years in Bukowski's life remain unknown. He might have worked in a German office until the Soviets regained control over Vilnius. It is confirmed that Bukowski and his wife supported themselves by making First Communion outfits and selling Christmas cards of their own making [illus. 24]. According to the information found in correspondence, they were able to produce 1,000 cards in 2-3 weeks, which must have helped to balance their household budget ${ }^{72}$.

Bukowski married Placyda Siedlecka (1907-1974), a Białystok-born art faculty graduate of Stephen Báthory University, in $1937^{73}$ [illus. 25]. According to available documents, they lived in several different places in Vilnius: 14 Montwiłłowska St. (now J. Tumo-Vaižganto St., the building probably does not exist anymore), 6/6 Arsenalska St. (now T. Vrublevskio St.), 13 Dominikańska St. (now Dominikonų St.), 16a Zaułek Zakretowy

70 Stanisław Bukowski (1903 - 22 August 1977), born in Dowgieliszki in Kaunas county. Construction engineer, Kaunas University graduate, member of Lauda corporation, youth activist in Lithuania. In 1930-1931 a member of the Polish Academic Youth Association in Lithuania, a member of the Socio-Cultural Association 'Pochodnia' board in Kaunas from 1935, a member of the Audit Committee in Polish Club. A teacher at Polish Gymnasium in Panevėžys. He arrived in Poland in 1947, he was a member of the academic staff at the Institute of Organisation and Mechanised Construction in Warsaw [after: Rocznik Warszawski, Warszawa: Muzeum Historyczne m. st. Warszawy, 1984, vol. XVII, p. 455; Mieczysław Jackiewicz, Polskie życie kulturalne w Republice Litewskiej 1919-1940 (Polish cultural life in the Republic of Lithuania), Olsztyn: Wyższa Szkoła Pedagogiczna, 1997, pp. 247, 271, 289; Idem, Polacy na Litwie 1918-2000: Słownik biograficzny (The Polish in Lithuania 1918-2000: Biographical dictionary), Warszawa: Wydawnictwo Andrzej Frukacz, 2003, p. 31; Konrad Łapin, Gtos z Litwy: lata 1922-1939 (The Voice from Lithuania: years 1922-1939), Gdańsk: Wydawnictwo „Marpress”, 1998, p. 84; Bohdan Paszkiewicz, Pod znakiem „Omegi” (Under the Sign „Omega”), Warszawa: Wydawnictwo Neriton / Instytut Historii PAN, 2003, p. 41; Architecture of Optimism. The Kaunas Penomenon 1918-1940: Travelling exhibition catalogue, Ed. Marija Drèmaite, Vilnius: Lapas, 2018, p. 286; Žilvinas Rinkšelis, „House of bus holder Lionginas Juknevičius”, in: Kaunas 2022 Modernizmas ateičiai, [online], [cited 2019-11-29], https://modernizmasateiciai.lt/en/autobususavininko-l-jukneviciaus-namas/; „House of Lionginas Junknevičius”, in: Architektūros ir urbanistikos tyrimų centras, [online], [cited 2019-11-29], http://www.autc.lt/en/architecture-objects/1925.

71 Rasa Antanavičiūtè, „Urban Development”, p. 324.

72 In the collection of the Sleńdziński Gallery in Białystok there are several postcards, among them two dated 18 December and 6 April 1944 with correspondence between the Bukowskis and their family.

73 Izabela Suchocka, op. cit., p. 45. 


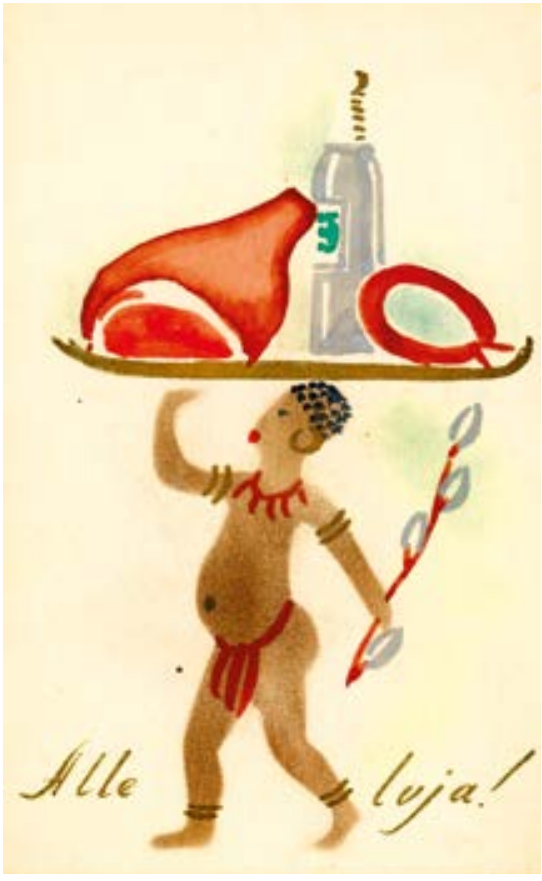

24.

A Christmas postcard by Placyda and Stanisław Bukowski, 1944, Sleńdziński Gallery in Białystok collection

Placydos ir Stanisławo Bukowskių kalėdinė atvirutė, 1944

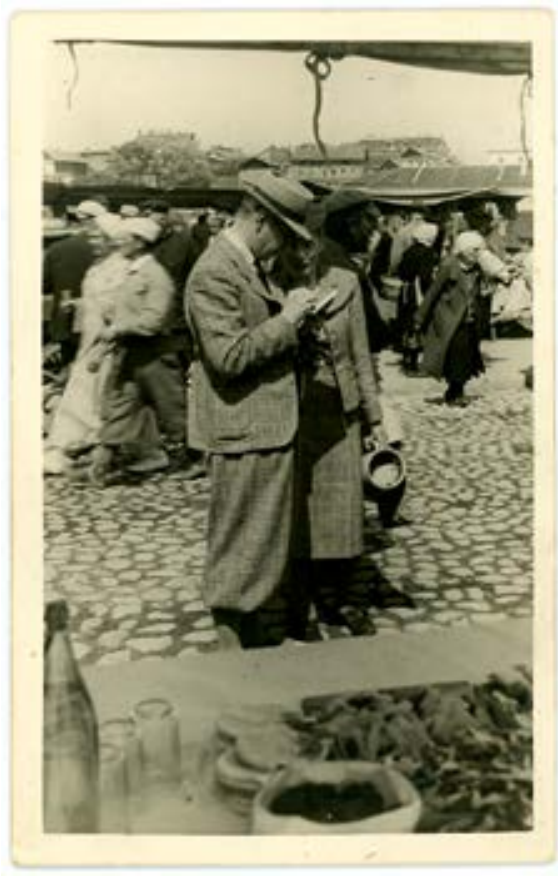

25.

Placyda and Stanisław Bukowski at a street fair in Vilnius, late 1930s, Sleńdziński Gallery in Białystok collection

Placyda ir Stanisławas Bukowskiai Vilniaus gatvès mugèje, XX a. 4 deš. pab.

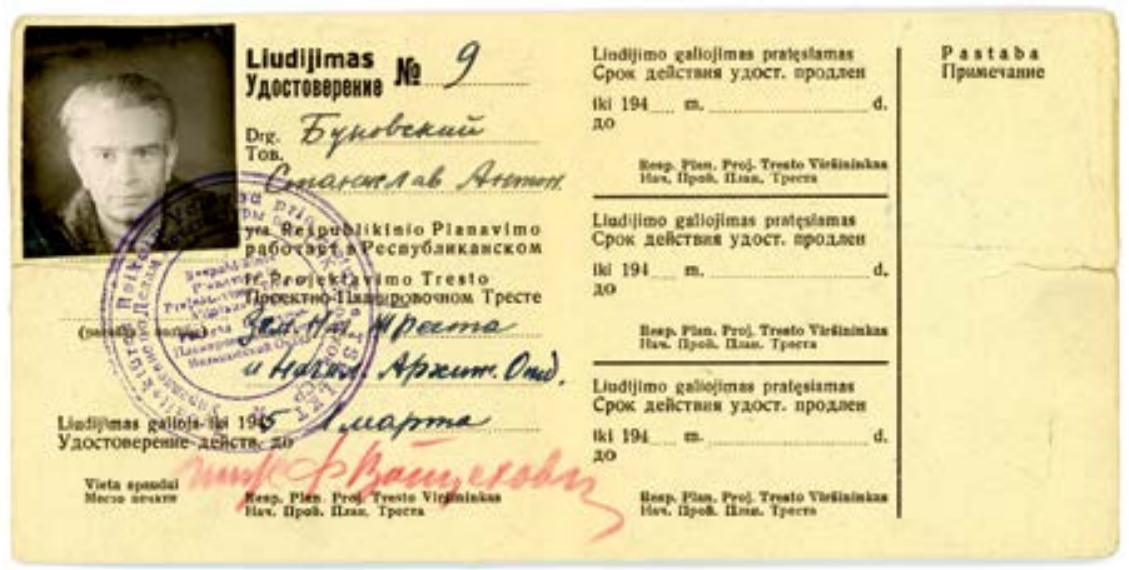

26.

S. Bukowski's work identification card as the deputy chief architect at the Design and Planning Republic Trust in Vilnius, 1945, Sleńdziński Gallery in Białystok collection
Stanisławo Bukowskio, Respublikinio projektavimo ir planavimo tresto Vilniuje vyriausiojo architekto, identifikavimo kortelè, 1945 
(now K. Donelaičio St.) ${ }^{74}$. Bukowski and his wife planned to spend their future life in Vilnius, which may be suggested by the fact that - several days before the outbreak of World War II - they had bought a building plot in the Popławy (now Paupys) quarter of Vilnius. Interestingly enough, the development project for the area in question was created by Jerzy Kobzakowski in the City Bureau for Urban Development just two years before ${ }^{75}$.

At the beginning of January 1945, Bukowski became the deputy head of the chief architect at the Respublikinis projektavimo ir planavimo trestas (Design and Planning Republic Trust in Vilnius) ${ }^{76}$ [illus. 26]. Due to the changes in the geopolitical situation, Stanisław was evacuated to Białystok in April $1945^{77}$, to his wife's home city. Placyda arrived there earlier via Lublin $^{78}$. Their friends from Vilnius: Władysław Paszkowski, Leszek Teodozy Dąbrowski, Fr Piotr Śledziewski PhD, as well architects of the younger generation such as Mieczysław Krzywiec or Michał Bałasz also settled in Białystok [illus. 27]. The rest decided to stay in Gdańsk, Torun and Warsaw ${ }^{79}$. That was the beginning of a new stage in Bukowski's career as an architect. Nevertheless, it was in Vilnius that his artistic personality developed and was influenced by both: the generation of Warsaw architects representing modernism ideals as well as historicism and respect for cultural heritage characteristic to the conservative Vilnius community. The charm of Vilnius made a lasting impression on Bukowski and the traditional architecture

74 Addresses established on the basis of personal documentation and work identification cards in the collection of Sleńdziński Gallery in Białystok, unsigned.

75 „O piękno Wilna w całej krasie” (Oh the Beauty of Vilnius in all its Glory), in: Kurjer Wileński, 1937, No. 95, p. 2; M. Tr., „Przyszłe Wilno: 6. Popławy” (Future Vilnius: 6. Popławy), in: Dziennik Wilenski, 1937, No. 114, p. 4.

76 Sleńdziński Gallery in Białystok, Authorising document No. 9 dated 30 January 1945 by the head of Design and Planning Republic Trust in Vilnius, unsigned.

77 Arkadiusz Gawroński, Działalność Wojewódzkiego Oddziału Państwowego Urzędu Repatriacyjnego w Biatymstoku w latach 1945-1950 (The activity of Provincial Department of the State Repatriation Office in Białystok in years 1945-1950), Białystok: Archiwum Państwowe w Białymstoku, 2012, data from a CD attached to the publication.

78 Authorising document of evacuation to Poland No. (illegible) dated 16 February 1945 by head representative of Polish Committee of National Liberation, in the collection of Joanna Łempicka from Białystok.

79 The collection of Joanna Łempicka, which is partly in deposit in the Sleńdziński Gallery in Białystok, serves as particularly interesting research material into the legacy of artists who emigrated from Vilnius after World War II. Apart from documents and works by Bukowski and his wife Placyda, the collection also includes works by other Vilnius artists who remained the Bukowskis' friends for many years after leaving Vilnius, for instance: Romana Gintyłówna, Hanna Milewska, Krystyna Wróblewska, Olga Żukowska, Koźma Czuryło, Vladas Drėma, Tadeusz Godziszewski, Ildefons Houwalt, Leon Kosmulski, Edward Machnacz and Adolf Popławski. 


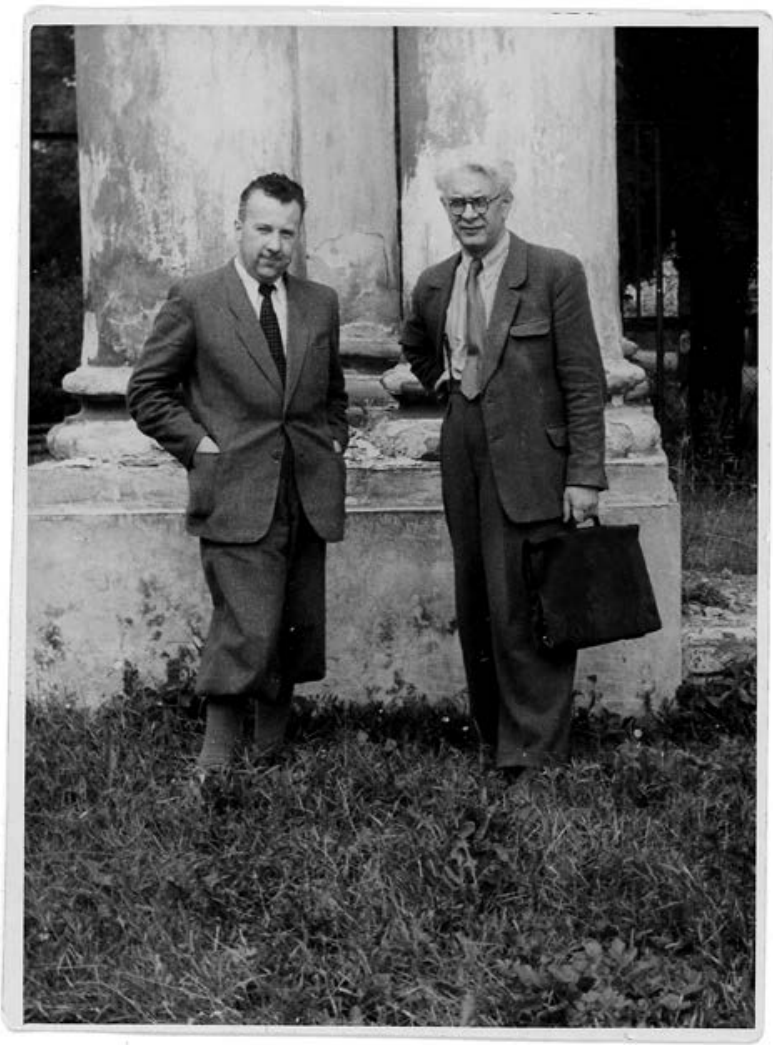

27.

Stanisław Bukowski and Władysław Paszkowski, the first Voivodeship Monument Conservator in Białystok, photograph by Władysław Paszkowski, 1948, Sleńdziński Gallery in Białystok collection

Stanisławas Bukowskis ir Władysławas Paszkowskis, pirmasis vaivadijos paminklosaugininkas Balstogeje, Władysławo Paszkowskio nuotrauka, 1948

of Białystok reminded him of the Lithuanian city. The argument may be supported by a comment in Gazeta Wspótczesna from a Białystok architect, Idzi W. Łukaszewicz on the first anniversary of Bukowski's death: "I also remember him drawing a comparison between the wooden architecture of Białystok and that of the Vilnius suburbs and his appeal to preserve the urban complex in its current state which in a few years' time would become a unique example of authentic construction trade practices in the Polish eastern territories" $"$.

Translated by Karolina Bielska 


\section{Bibliography}

\section{Source materials}

The collection of Joanna Łempicka from

Białystok, Materials regarding the life and work of Placyda and Stanisław Bukowski (documents, correspondence, art works).

Galeria im. Sleńdzińskich w Białymstoku (Sleńdziński Gallery in Białystok), The deposit of Joanna Łempicka from Białystok regarding the life and work of Placyda and Stanisław Bukowski (documents, correspondence, photographs, artistic works, projects).

Biblioteka Narodowa w Warszawie (National Library of Poland in Warsaw), [Materiały dotyczące biografii Stanisława Bukowskiego, jego działalności zawodowej i twórczości (Materials concerning the biography, career and works of Stanisław Bukowski)], f. Rps akc. 12134.

Politechnika Warszawska w Warszawie (Warsaw University of Technology in Warsaw), Student Registration Department, Student Files Archive, [Stanisław Bukowski's File], No. 7243 .

\section{Books}

Antanavičiūtė Rasa, Menas ir politika Vilniaus viešosiose erdvese (Art and politics in Vilnius Public Spaces), Vilnius: Lapas, 2019. Architecture of Optimism. The Kaunas Phenomenon 1918-1940: Travelling exhibition catalogue, Ed. Marija Drèmaitè, Vilnius: Lapas, 2018.

Bujnicki Teodor, Memoriat w sprawie urbanistyki wileńskiej o prawdziwa estetyke miasta (A memorial for city aesthetics regarding urban planning in Vilnius), Wilno: Zakłady Graficzne Znicz, 1937.

Gawroński Arkadiusz, Działalność Wojewódzkiego Oddziatu Państwowego Urzędu Repatriacyjnego w Biatymstoku w latach 1945-1950 (The activity of the Provincial
Department of the State Repatriation Office in Białystok in the years 1945-1950), Białystok: Archiwum Państwowe w Białymstoku, 2012.

Gisges Jan Maria, Wywotywanie duchów (Invoking Spirits), Warszawa: Ludowa Spółdzielnia Wydawnicza, 1985.

Jackiewicz Mieczysław, Polacy na Litwie 1918-2000: Słownik biograficzny (The Polish in Lithuania: Biographical dictionary), Warszawa: Wydawnictwo Andrzej Frukacz, 2003.

Jackiewicz Mieczysław, Polskie życie kulturalne w Republice Litewskiej 1919-1940 (Polish cultural life in the Republic of Lithuania), Olsztyn: Wyższa Szkoła Pedagogiczna, 1997.

Kucza-Kuczyński Konrad, Twórcy i dzieła Warszawskiej Szkoły Architektury 1915-2015 (Creators and works of Warsaw School of Architecture 1915-2015), Warszawa: Oficyna Wydawnicza Politechniki Warszawskiej, 2017.

Łapin Konrad, Gtos z Litwy: lata 1922-1939 (The Voice from Lithuania, years 19221939), Gdańsk: Wydawnictwo Marpress, 1998.

Łoza Stanisław, Czy wiesz kto to jest? (Do you know who this is?), Warszawa: Wydawnictwo Głównej Księgarni Wojskowej, 1938.

„Materiały do dziejów sztuki sakralnej na ziemiach dawnej Rzeczypospolitej" (Materials on the history of religious art in the former Polish Commonwealth territory), in: Kościoły i klasztory rzymskokatolickie dawnego województwa wileńskiego (Roman Catholic churches and monasteries in the former Vilnius Voivodeship), Kraków: Międzynarodowe Centrum Kultury, 2005, pt III, vol. I, Ed. Maria Kałamajska-Saeed.

Misius Kazys, Šinkūnas Romualdas, Lietuvos kataliku bažnyčios: Žinynas (The Catholic Churches of Lithuania: A Handbook), Vilnius: Pradai, 1993.

(Ne)matomas Vilnius: tarpukario dailes ir architektūros pavidalai: Parodos katalogas, 
Vytauto Kasiulio dailès muziejus /

(In) visible Vilnius: Shapes of Interwar Art and Architecture: Exhibition catalogue, Vytautas Kasiulis Art Museum, Ed. Monika Grigūnienè, Vilnius: Vilniaus dailès akademijos leidykla, 2018.

Paszkiewicz Bohdan, Pod znakiem „Omegi”, Warszawa: Wydawnictwo Neriton / Instytut Historii PAN, 2003.

Politechnika Warszawska. Sktad osobowy $i$ plan studiów na rok akademicki 1934/35 (Warsaw University of Technology. Faculty composition and syllabus for academic year 1934/35), Warszawa: Politechnika Warszawska, 1934.

Program i warunki konkursu powszechnego S.A.R.P. XCI na projekt szkicowy Zaktadu Zastawniczego Komunalnej Kasy Oszczędności w Wilnie ogłoszony na zlecenie Komunalnej Kasy Oszczędności miasta Wilna (The Programme and Regulations of the S.A.R.P. (Association of Polish Architects) XCI General Competition for a Draft Project of a Lombard House of the Municipal Savings Bank in Vilnius announced by Municipal Savings Bank in Vilnius), Wilno: Stowarzyszenie Architektów Rzeczypospolitej Polskiej Oddział w Wilnie, 1937.

Pszczółkowski Michał, Kresy nowoczesne. Architektura na ziemiach wschodnich II Rzeczypospolitej 1921-1939 (Modern Eastern Borderlands. The architecture in the Eastern Territory of the Second Polish Republic 1921-1939), Łódź: Księży Młyn, 2016.

Rocznik Warszawski, vol. XVII, Warszawa: Muzeum Historyczne m. st. Warszawy, 1984.

Romuald Gutt, Ed. Olgierd Czerner, Warszawa: Arkady, 1968.

Sokołowska Małgorzata, Kwiatkowska Wiesława, Gdyńskie cmentarze. O twórcach miasta, portu i floty (Cemeteries of Gdynia. About the creators of the city, port and fleet), Gdynia: Oficyna VERBI CAUSA, 2003.

Stefan Narębski (1892-1966) - architekt, konserwator, profesor (Stefan Narębski (1892-1966) architect, conservator, professor), Ed. Marek Rubnikowicz, Torun: Muzeum Okręgowe w Toruniu, 2017.

Suchocka Izabela, Placyda Bukowska (190\%-1974). W stulecie urodzin (Placyda Bukowska (1907-1974). 100th Birthday Anniversary), Białystok: Galeria im. Sleńdzińskich w Białymstoku, 2007.

Targi Pótnocne w Wilnie. Czym były - czym sa-czym maja być (Northern Trade Fair in Vilnius. What they were - what they are - what they will be), Wilno: Towarzystwo Targów Północnych w Wilnie, 1939.

Vilnius 1900-2013. A guide to the city's architecture, Ed. Julija Reklaitè, Rūta Leitanaitè, Vilnius: Architektūros Fondas, 2013.

Wicher Sebastian, Żyć architektura. Życie $i$ twórczość architekta Stanistawa Bukowskiego (1904-1979) (To live architecture. Life and work of architect Stanisław Bukowski (1904-1979), Białystok: Stowarzyszenie Architektów Polskich Oddział w Białymstoku / Studio Wydawnicze UNIKAT, 2009.

Wilno XX-XXI. Przewodnik architektoniczny (Vilnius XX-XXI. Architectural Guide), Ed. Marija Dremaitè, et al., Warszawa: Fundacja Centrum Architektury, 2019.

\section{Journals / Book articles}

„Aleja z Ostrej-Bramy do Kalwarji” (The alley from the Gate of Dawn to Kalwaria), in: Wieczorna Gazeta Wileńska, 1938, No. 58, p. 2.

Antanavičiūtė Rasa, „Urban Development in Vilnius during the Second World War", in: Art and Artistic Life during the Two World Wars, Ed. Giedrè Jankevičiūtè, Vilnius: Lithuanian Culture Research Institute, 2012, p. 319-350.

Batorowicz Józef, „Mauzoleum królewskie w Wilnie" (Royal mausoleum in Vilnius), in: Gazeta Polska, 1937, No. 182, p. 3.

Bortnowski Władysław, „Przegląd prac konserwacyjnych na Górze Zamkowej w Wilnie w latach 1930-1936” (Review
$98-2020$

Acta Academiae Artium Vilnensis 
of renovation works at the Castle Hill in Vilnius 1930-1936), in: Ateneum Wilenskie, 1938, No. 1, pp. 211-216.

Bukowski Stanisław, „List do Redakcji” (A letter to the editorial office), in: Stowo, 1937, No. 20, p. 6 and Kurjer Nowogródzki, 1937, No. 20 , p. 6 .

Ch. J., „Wojna o Wilno” (A War over Vilnius), in: Dziennik Wilenski, 1936, No. 102, p. 7.

„Co się ma stać w sporcie wileńskim” (What is to happen in Vilnius Sport?), in: Dziennik Wilenski, 1937, No. 225, p. 4.

Dolistowska Małgorzata, „Miłe miasto” między tradycją a awangardą. Architektura Wilna w dwudziestoleciu międzywojennym - zarys problematyki" (A nice city - tradition and avant-garde. The architecture of Vilnius in the interwar period - an overview), in: Stan badan nad wielokulturowym dziedzictwem dawnej Rzeczypospolitej (The State of Research on Multicultural Heritage in the Old Commonwealth), vol. VIII, Ed. Wojciech Walczak, Karol Łopatecki, Białystok: Instytut Badań nad Dziedzictwem Kulturowym Europy, 2017, p. 87-149.

„Dorobek wileńskiego LOPP” (The Legacy of Air and Chemical Defense League in Vilnius), in: Kurjer Wileński, 1937, No. 96, p. 2.

(e), „Gdzie stanie pomnik A. Mickiewicza? Plac Orzeszkowej wykreślony z rachuby" (Where will the A. Mickiewicz monument be built? Orzeszkowa Square is off the list), in: Dziennik Wilenski, 1937, No. 41, p. 5.

Jotha (Jerzy Hoppen), „Jeszcze o figurach świętych na Bazylice Wileńskiej" (More about the statues of saints on the Basilica in Vilnius), in: Stowo, 1937, No. 21, p. 6 and Kurjer Nowogródzki, 1937, No. 21, p. 6.

Kieniewicz Kazimierz, „Problem Placu Katedralnego w Wilnie" (The matter of the Cathedral Square in Vilnius), in: Architektura i Budownictwo, 1938, No. 11/12, pp. 373-375.

„Komitet Obywatelski obchodu 25-lecia wileńskiej Dyw. Legionowej” (Citizens' Commiittee of $25^{\text {th }}$ Anniversary of Vilnius
Legions Division), in: Kurjer Wileński, 1939, No. 203, p. 2.

„Konferencja w sprawie restauracji Bazyliki Wileńskiej" (Conference about the restoration of Basilica in Vilnius), in: Kurjer Wileński, 1937, No.63, p. 2.

„Konkurs na szkicowy projekt pomnika Marszałka Józefa Piłsudskiego w Wilnie" (A competition for a sketch design of Marshall Józef Piłsudski monument in Vilnius), in: Architektura i Budownictwo, 1939, No. 4/5, pp. 57-59.

„Lista rzeczoznawców urbanistycznych Związku Miast Polskich" (List of Urban Surveyors in the Association of Polish Cities), in: Biuletyn Urbanistyczny, 1938, No. 2, p. 62.

„Lombard w nowym gmachu” (The New Building of Lombard House), in: Kurjer Wilenski, 1939, No. 226, p. 4.

Łukaszewicz Idzi, „Konterfekt architekta” (The Portrait of an Architect), in: Gazeta Wspótczesna, 1980, No. 54, p. 6.

Małachowicz Edmund, „Architektura dwudziestolecia międzywojennego w Wilnie" (The architecture of interwar period in Vilnius), in: Studia i materiały do teorii i historii architektury i urbanistyki (Studies and materials on the theory and history of architecture and urban planning), Warszawa: Państwowe Wydawnictwo Naukowe, 1989, vol. XVII: Architektura i urbanistyka w Polsce w latach 1918-1978 (Architecture and urban planning in Poland in 1918-1978), Ed. Wojciech Kalinowski, pp. 121-141.

Michalski Edmund, „Wrażenia z podróży do Hiszpanji" (Impressions from a trip to Spain), in: Architektura i Budownictwo, 1929, No. 5, pp. 186-195.

„Nie zakwalifikowano żadnego z 54 projektów na pomnik Marszałka Piłsudskiego" (None of the 54 projects of Piłsudski monument selected), in: Stowo, 1939, No. 106, p. 5.

„O piękno Wilna w całej krasie” (Oh the Beauty of Vilnius in all its Glory), in: Kurjer Wileński, 1937, No. 95, p. 2. 
„Otwarcie wystawy prac ,grupy wileńskiej” i wystawa projektów na pomnik Marsz. Piłsudskiego" (Opening of the exhibition of works by 'Vilnius Group' and Piłsudski monument projects exhibition), in: Stowo, 1939, No. 107, p. 7.

P. K., „Kronika wileńska” (Vilnius chronicle), in: Biuletyn Historii Sztuki i Kultury, 1937, No. 1, pp. 100-101.

Pawłowski Krzysztof, „Zasady ochrony, odbudowy i rewaloryzacji historycznych zespołów urbanistycznych” (Regulations concerning the preservation, renovation and restoration of historical urban complexes), in: Zabytki urbanistyki $i$ architektury $w$ Polsce. Odbudowa i konserwacja (Urban and architectural monuments in Poland. Restoration and conservation), Ed. Wiktor Zin, vol. 1: Miasta historyczne (Historical cities), Ed. Wojciech Kalinowski, Warszawa: Arkady, 1986, p. 48-67.

Poklewski Józef, „Przyczynek do dziejów artystycznego Wilna w dwudziestoleciu międzywojennym" (Contribution to the history of art in Vilnius in interwar period), in: Studia z historii sztuki i kultury wileńskiej lat 1900-1945. Wybór tekstów (The study of art history and culture in Vilnius in years 1900-1945. Selected texts), Ed. Elżbieta Pilecka, Alicja Saar-Kozłowska, Małgorzata Wawrzak, Toruń: Wydawnictwo Naukowe Uniwersytetu Mikołaja Kopernika, 2019, pp. 145-190.

„Pomnik A. Mickiewicza stanie w ogrodzie po-bernardyńskim" (A. Mickiewicz Monument in the former Bernardine Garden), in: Dziennik Wileński, 1937, No. 48, p. 5.

„Poradnia do spraw obrony przeciwlotniczej” (Airborne and antigas defence information bureau), in: Gazeta Wileńska, 1939, No. 242, p. 3.

„Poradnia do spraw O. P. L.-Gaz.” (Airborne and antigas defence information bureau), in: Goniec Poranny, 1939, No. 168, p. 4. „Protokół 2 posiedzenia Sądu Konkursowego na Targi Północne w Wilnie" (The minutes of $2^{\text {nd }}$ meeting of Competition
Panel for Northern Trade Fair in Vilnius) and „Protokół ostatecznego posiedzenia Sądu Konkursowego na Targi Północne w Wilnie" (The minutes of the final meeting of Competition Panel for Northern Trade Fair in Vilnius) in: Komunikat SARP, 1938, No. 4-5, pp. 6-9.

„Przyszłe Wilno: 1. Biuro Urbanistyczne” (Future Vilnius: 1 Urban Planning Office), in: Dziennik Wileński, 1937, No. 104, p. 4.

(S), „Zadrzewienie ulic, parki, bulwary... Plany Biura Urbanistycznego" (Tree planting in streets, parks and promenades...Urban Planning Office plans), in: Dziennik Wileński, 1937, No. 15, p. 5.

„Sprawy urbanistyczne Wilna na posiedzeniu Magistratu" (Vilnius urban issues at the City Hall Meeting), in: Kurjer Nowogródzki, 1938, No. 95, p. 5.

Srebrakowski Aleksander, „Targi Północne w Wilnie 1928-1939" (Northern Trade Fair in Vilnius 1928-1939), in: Wokót historii i polityki. Studia z dziejów XIX $i$ XX wieku dedykowane Profesorowi Wojciechowi

Wrzesińskiemu w siedemdziesiąta rocznice urodzin (On history and politics. Studies of 19th and 20th century dedicated to Professor Wojciech Wrzesiński on his seventieth brithday), Ed. Stanisław Ciesielski, et al., Toruń: Wydawnictwo Adam Marszałek, 2004, pp. 781-787.

Śledziewski Piotr PhD, „Sprawa dwóch pomników w Wilnie - Marszałka Piłsudskiego i Mickiewicza" (The case of two monuments in Vilnius - of Marshall Piłsudski and Mickiewicz), in: Kurjer Wileński, 1936, No. 229, p. 7.

Śledziewski Piotr, Bukowski Stanisław, „O projekcie regulacji Placu Katedralnego w Wilnie w związku z zamierzoną budowa pomnika pierwszego marszałka Polski Józefa Piłsudskiego" (On the project of regulation of the Cathedral Square in Vilnius in connection to the erection of the monument of the First Marshall of Poland Józef Piłsudski), in: Architektura i Budownictwo, 1938, No. 11/12, pp. 366-372.
$98-2020$

Acta Academiae Artium Vilnensis 
Śledziewski Piotr, „Mauzoleum Królewskie w Bazylice Wileńskiej” (Royal mausoleum in Basilica in Vilnius), in: Wilno, 1939, No. 2, pp. 107-119.

Tr. M., „Mauzoleum Królewskie w Bazylice Wileńskiej” (Royal mausoleum in Basilica in Vilnius), in: Dziennik Wileński, 1937, No. 176, p. 4.

Tr. M., „Przyszłe Wilno: 6. Popławy” (Future Vilnius: 6. Popławy), in: Dziennik Wileński, 1937, No. 114, p. 4.

„W 20-letnią rocznicę odzyskania Wilna” (On the 20th anniversary of regaining Vilnius), in: Gtos Narodowy, 1939, No. 107, p. 5.

Wojciechowski Jarosław, „Pałac Wilanowski i jego obecna restauracja" (Wilanowski Palace and its current restoration), in: Architektura i Budownictwo, 1928, No. 3, pp. 81-106.

Wójcicki Kazimierz, „Wznowienie Targów Północnych" (Revival of the Northern Trade Fair), in: Nasze Sprawy, 1938, No. 9, pp. 1-2.

(z), ,Strefy budowlane Wilna w opracowaniu Miejskiego Biura Urbanistycznego" (Construction Zones in Vilnius elaborated by The City Bureau for Urban Development), in: Kurjer Wileński, 1939, No. 60, p. 5.

„Z Komisji Urbanistycznej Związku Miast Polskich" (At the Association of Polish Cities Urban Commission), in: Biuletyn Urbanistyczny, 1938, No. 3-4, p. 71.

\section{Worldwide Websites}

„Liepkalnio“ gimnazijos rekonstravimas (Reconstruction of Liepkalnis Gymnasium), in: Unitectus architektų grupè, [online], [cited 2019-11-29], http://www.unitectus.lt/ lt/project/liepkalnio-gimnazijos-atnaujinimas-vilnius.html.

„Piotr Śledziewski”, in: Wikipedia - The Free Encyclopedia, [online], [cited 2019-11-28], https://pl.wikipedia.org/wiki/Piotr_Śledziewski.
Rinkšelis Žilvinas, „House of bus holder Lionginas Juknevičius", in: Kaunas 2022 Modernizmas ateičiai, [online], [cited 201911-29], https://modernizmasateiciai.lt/en/ autobusu-savininko-l-jukneviciaus-namas/; „House of Lionginas Junknevičius”, in: Architektūros ir urbanistikos tyrimų centras, [online], [cited 2019-11-29], http://www.autc. lt/en/architecture-objects/1925.

Wołkanowski Waldemar, „Zanim zniknie „Žalgiris”, czyli jak powstawał stadion w Wilnie" (Before 'Žalgiris' is gone, or the story behind the construction of the stadium in Vilnius), in: Wilnoteka, [online], 17 November 2017, [cited 2019-11-29], http://www. wilnoteka.lt/artykul/zanim-zniknie-quotzalgirisquot-czyli-jak-powstawal-stadion-w-wilnie. 
Santrauka

\section{Architektūrinis Stanisławo Bukowskio palikimas Vilniuje - indèlis ị tolesnius tyrimus}

Sebastian Wicher

Reikšminiai žodžiai: architektas Stanisławas Bukowskis (1904-1979), modernioji architektūra, Vilniaus architektūra ir urbanistinis planavimas, Vilniaus paminklai, Vilniaus meninis gyvenimas, tarpukario Vilnius, Vilnius Antrojo pasaulinio karo metu.

Straipsnyje pateikiama išsami Stanisławo Bukowskio - architekto, miesto inžinieriaus, paminklosaugininko ir Varšuvos technologijos universiteto Architektūros fakulteto absolvento (1933) - kūrybinè biografija. Bukowskis gyveno ir dirbo Vilniuje 1936-1945 metais. Sebastiano Wicherio 2009 m. publikuota monografija Gyventi architektūra. Stanisławo Bukowskio (1904-1979) gyvenimas ir kūryba šiandien reikalauja patikslinimų ir papildomų Vilniaus periodo palikimo tyrimų. 1936-1940 m. laikotarpiu Stanisławas Bukowskis dirbo Vilniaus miesto urbanistinio planavimo ir vystymo biure, kuriam vadovavo Varšuvos architektas Romualdas Guttas. Būdamas atsakingas už erdvinę architektūrą, jis dalyvavo daugelyje projektų, pavyzdžiui, Katedros aikštès (1936-1937), Pirmosios baterijos Arklių gatvèje ir Piligrimų tako pertvarkymo darbuose. Be to, projektavo viešuosius pastatus, gyvenamųjų namų kompleksus ir buvo ịsitraukęs i paminklų konservavimo darbus. 1937 m. Bukowskiui buvo įteiktas aukščiausias architektūros konkurso apdovanojimas už karališkojo mauzoliejaus Vilniaus arkikatedroje projektą, kuriam nusileido net tuometinio Vilniaus miesto architekto Stefano Narębskio konkursinis darbas. Kartu su R. Guttu jie suprojektavo funkcionalistinio stiliaus mokyklos pastatą Liepkalnyje (19381939) ir pagrindinius šiandien neišlikusio stadiono vartus Piromonte (1938). Taip pat jis suprojektavo bei prisidejo projektuodamas du modernistinius pastatus: Dambrovskio g. 14 (dab. A. Jakšto g. 14) esančius apartamentus 
M. Deul kompanijos darbuotojams ir Akmenų g. 5 šalia Tauro kalno esančią vilą, kurią jis suprojektavo kartu su Mose Cholemu. Prasidejjus Antrajam pasauliniam karui, nuo 1940 m. balandžio iki gruodžio Kauno rajono vykdomasis komitetas paskyrè Bukowski planuoti ir projektuoti šalia Kauno esantic Kulautuvos kurortą. Tuo pat metu jis rengè rekonstrukcini projektą, pagal kurị vietinė Šv. Petro koplyčia turèjo būti paversta Švč. Mergelès Marijos bažnyčia. Jis liko gyventi Vilniuje kartu su savo Balstogejje gimusia žmona Placyda Siedlecka-Bukowska - Stepono Batoro universiteto Dailès fakulteto absolvente. $1941 \mathrm{~m}$. balandžio 15 d. Bukowskis buvo paskirtas Vilniaus miesto matavimo ir planavimo valdybos pirmuoju sekretoriumi. Apie tris kitus Bukowskio gyvenimo metus nieko nežinoma. Iki pat sovietams atkovojus Vilnių jis galimai dirbo Vokietijos urbanistinio planavimo biure. Nuo 1945 m. sausio 30 d. iki kovo 1 d. Bukowskis dirbo Respublikiniame projektavimo ir planavimo treste Vilniuje kaip vyriausiasis architektas ir atsakingasis sekretorius. $1945 \mathrm{~m}$. balandi jis su žmona persikèlè ị Balstogę, kur ėmèsi pamiklų restauravimo ir architektūrinio projektavimo darbų. Profesinè veikla Vilniuje Bukowskio architektūrinei karjerai buvo itin svarbi. Vilniuje igyta patirtis neabejotinai turèjo itin didelę ittaką jo vèlesnei veiklai Balstogėje. Lenkijos ir Lietuvos tyrèjų neseniai atrasta archyvinė medžiaga kviečia imtis tolesnių Bukowskio kūrybinio palikimo tyrimų. 